\title{
The Effect of Planned Behavior Theory, Ethical Commitment, and Perceived Risk on Corporate Sustainability Accounting and Reporting
}

\author{
Hasan Abdollahzadeh \\ Assistant Professor of Psychology, Payame Noor University, Iran, Tehran. \\ Abdollahzadeh2002@yahoo.com \\ Vahid Amin* \\ Faculty of Accounting, Payame Noor University, Iran, Tehran \\ (Corresponding author) Vahid.amin1985@yahoo.com
}

\begin{abstract}
:
The present study aimed at investigating the role of attitude, sabjective norm, perceived behavior control, ethical commitment, and perceived risk on intention to corporate sustainability accounting and reporting(CSAR) on the Tehran Stock Exchange. This study is a survey research. The statistical population of this study included the financial managers and senior experts of accounting in the companies listed on the Tehran Stock Exchange except the financial intermediary companies such as banks, investment funds, insurances, etc. The population size was considered as 276 subjects each one representing one company. The statistical sample was determined as 161 subjects using Cochran formula at 5\% error level. In order to measure the research variables, a standard questionnaire with five-point Likert scale was used. The research questionnaire was randomly emailed to 200 companies listed on the Tehran Stock Exchange in 2019 to achieve the statistical sample size and finally 163 questionnaires were answered. In this study, the structural equations model was used to test the hypotheses. The results of structural equations model showed that attitude, mental norm, perceived behavior control, and ethical commitment have a positive effect on intention to CSAR. However, the significant effect of perceived risk of managers and accountants on intention to CSAR was not observed. The results of this study presented an extensive attitude among the goals of managers for intention to CSAR. Thus, the above-mentioned components can be used for CSAR to achieve a sustainable development.
\end{abstract}

Key Word: Theory of Planned Behavior, Ethical Commitment, Perceived Risk, Intention to Corporate Sustainability Accounting and Reporting.

Copyrights

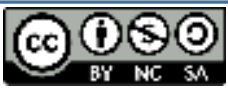

This license only allowing others to download your works and share them with others as long as they credit you, but they can't change them in any way or use them commercial. 
مقاله يְزوهشى

دو فصلنامه حسابدارى ارزشى و رفتارى- سال ينجه، شماره نهم، بهار و تابستان 99 ا، صفحه 99 99

\section{تاثير نظريه رفتار برنامه ريزى شده، تعهد اخلاقى و ادراك ريسك بر تمايل به حسابدارى و كزارشكرى ثايدارى شركتى \\ وحيد امين:"

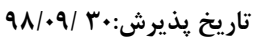 \\ حسن عبداله زادها

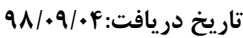

جكيده

تحقيق حاضر با هدف بررسى نقش نكَرش، هنجارذهنى، كنترل رفتارى ادراك شده، تعهد

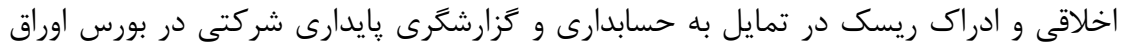

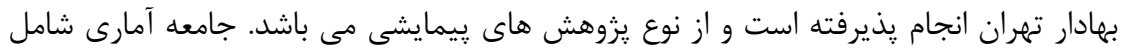

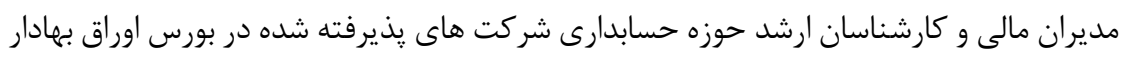

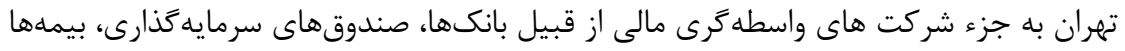

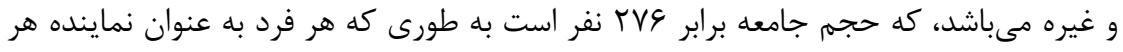

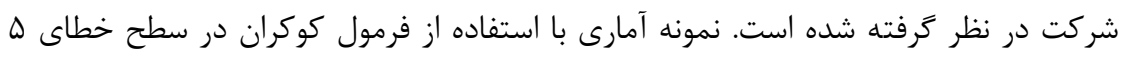

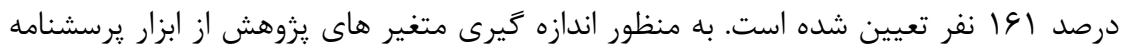

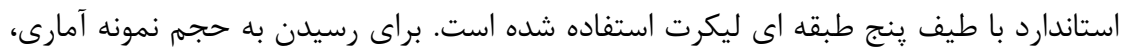

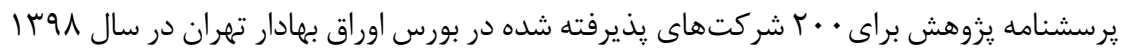

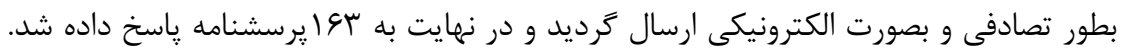

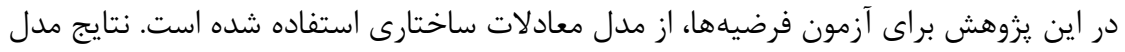

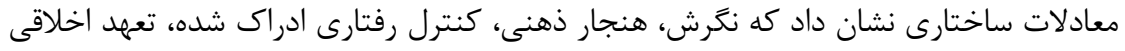

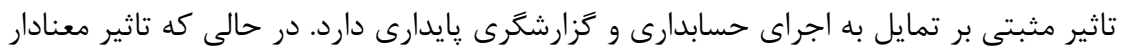

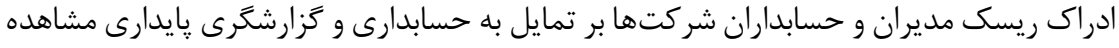

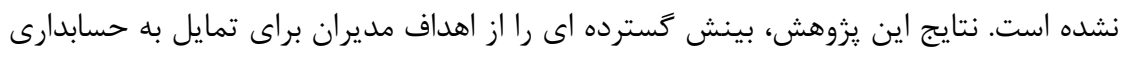

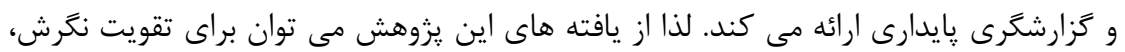

'استاديار، گروه روانشناسى، دانشگاه يُام نور، ايران، تهران Abdollahzadeh2002@yahoo.com

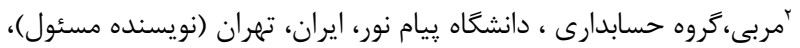
Vahid.amin1985@yahoo.com 
دو فصلنامه حسابدارى ارزشى و رفتارى، سال ينجه، شماره نهم، بهار و تابستانو9؟1

rV.

$$
\begin{aligned}
& \text { هنجار ذهنى، كنترل رفتار درك شده و تعهد اخلاقى جهت دركير شدن در حسابدارى و }
\end{aligned}
$$

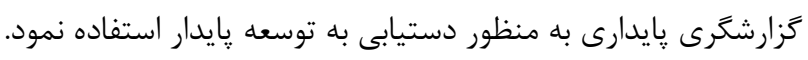

$$
\begin{aligned}
& \text { وازگَان كليدى: نظريه رفتار برنامهريزى شده، تعهد اخلاقى، ادراى ريسك، تمايل به اجراى } \\
& \text { حسابدارى و گزارشخرى يايدارى }
\end{aligned}
$$




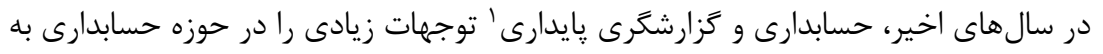

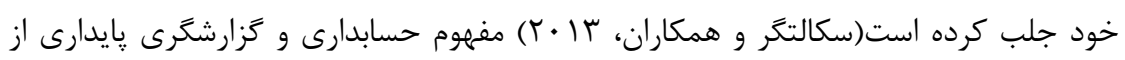

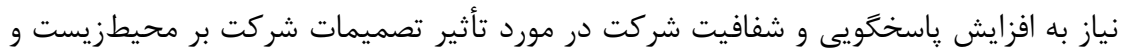

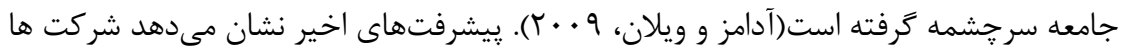

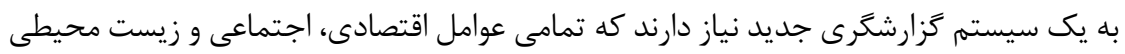

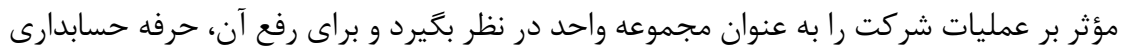

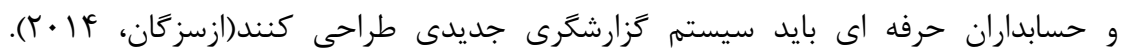

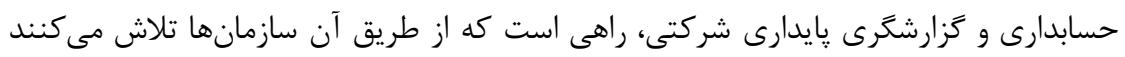

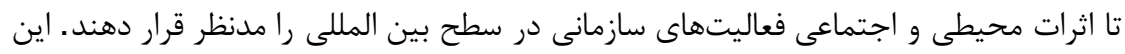

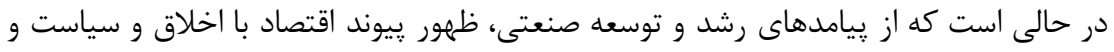

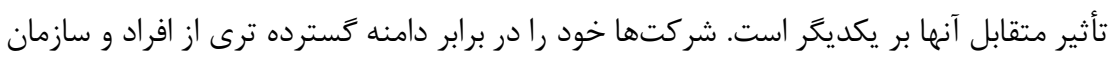

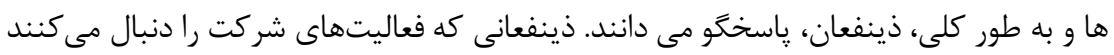

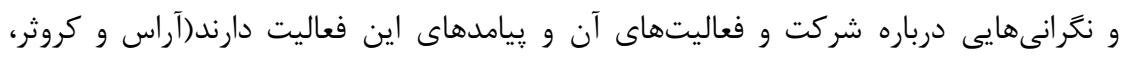

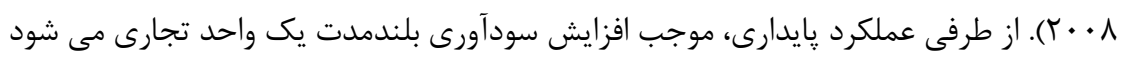

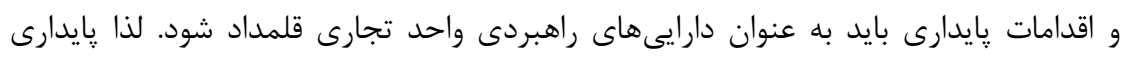

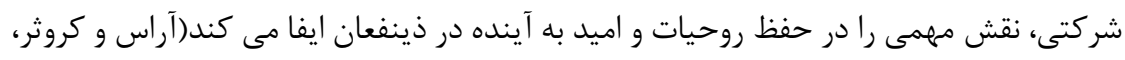

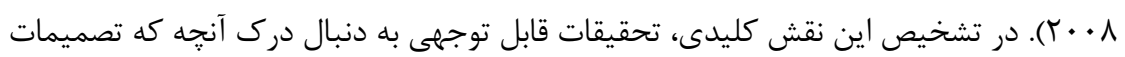

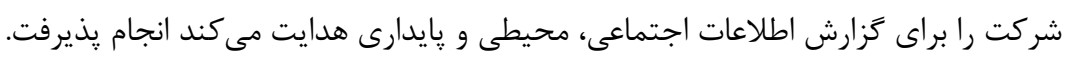

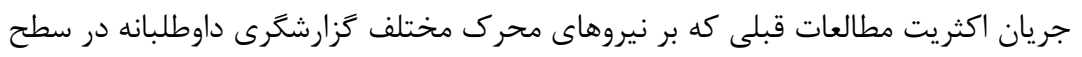

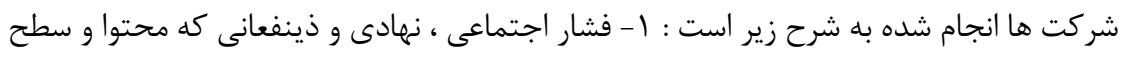

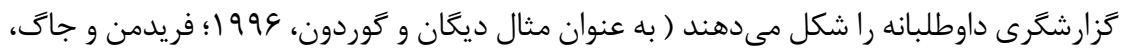

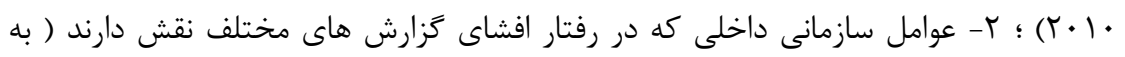

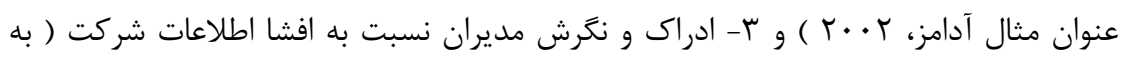

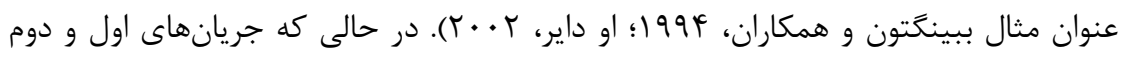

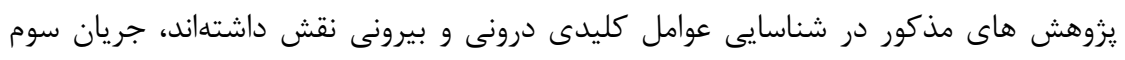

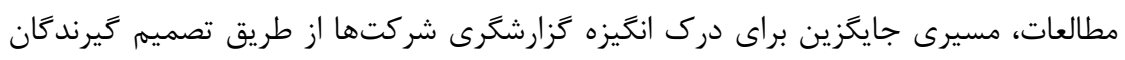

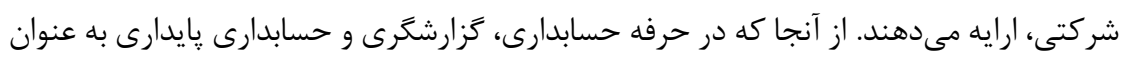

\footnotetext{
${ }^{1}$. Corporate Sustainability Accounting and Reporting
} 
رفتارى است كه منافع كل ذينفعان را در نظر مى گيرد، بسيار حائز اهميت است. معيار هايى كه

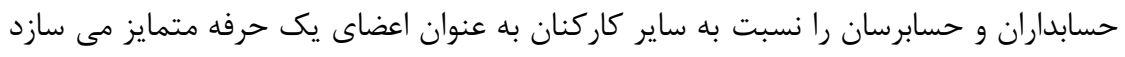

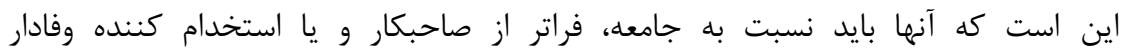

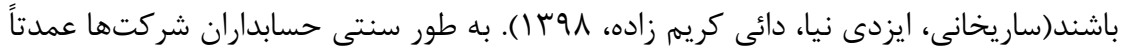

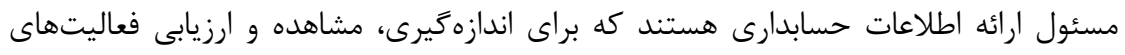

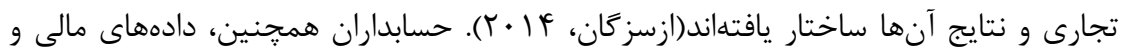

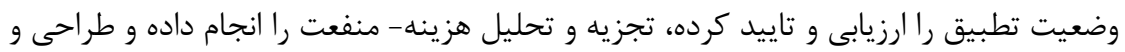

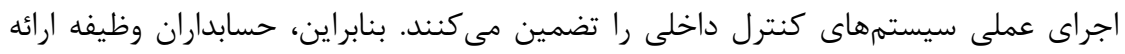

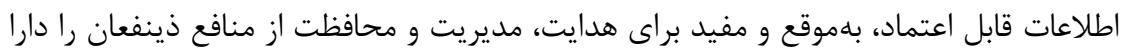

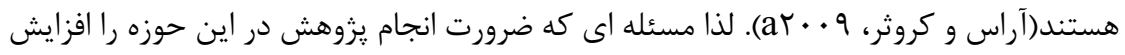

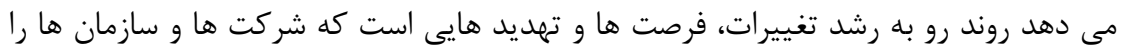

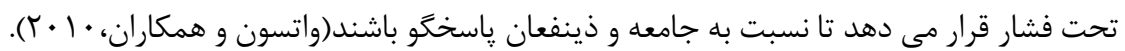
از طرفى ايران به عنوان يك كشور در حال توسعه به دنبال دستيابى به هشمه إنداز

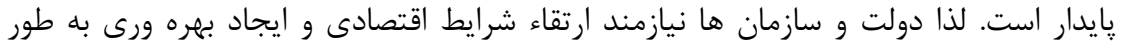

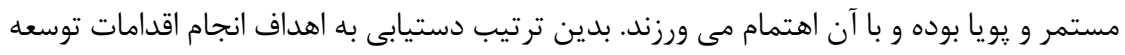

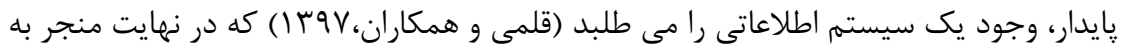

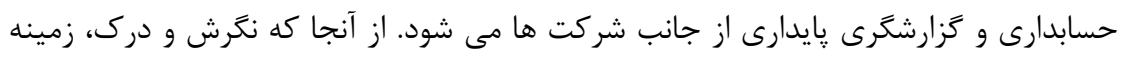

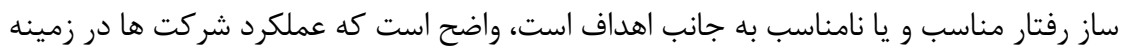

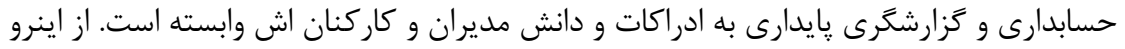

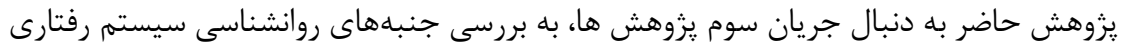

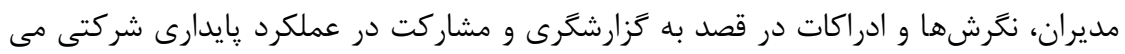

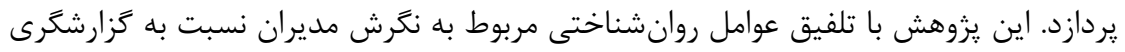

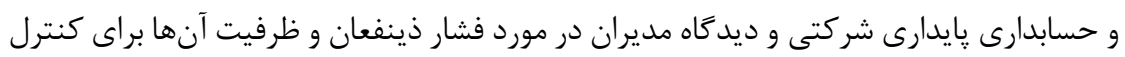

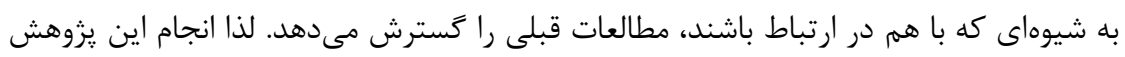

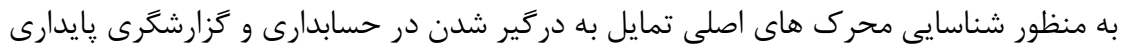

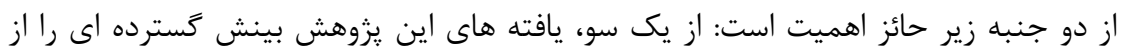

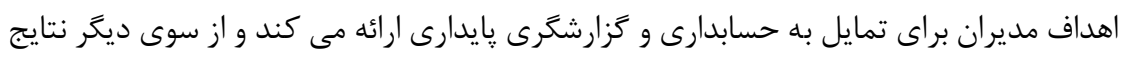

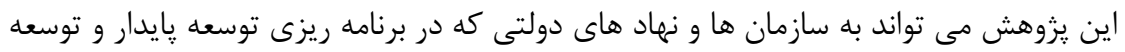

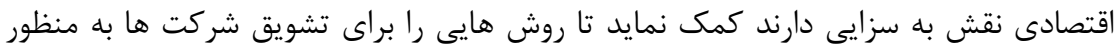

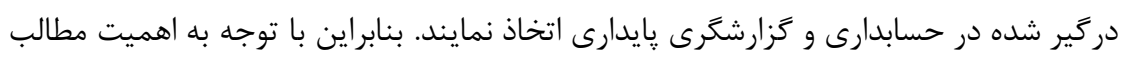


بيان شده، به نظر مى رسد متغيرهاى مختلفى بر اساس تئورى رفتار برنامه ريزى شده' (TPB)

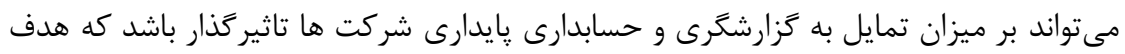

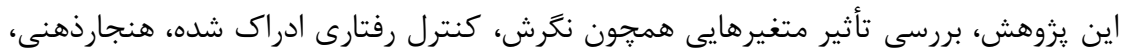

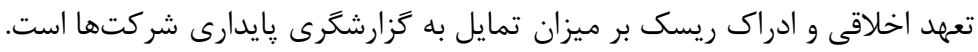

\section{r-مبانى نظرى و وبيشينه يخوهش

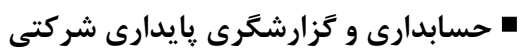

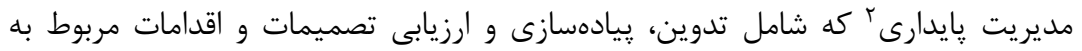

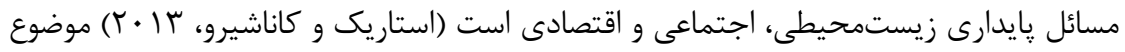

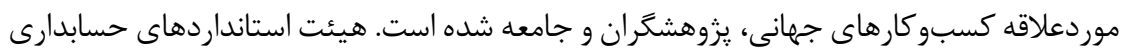

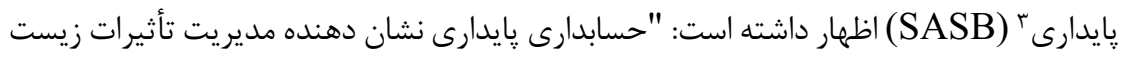

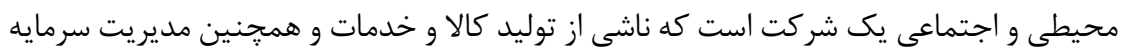

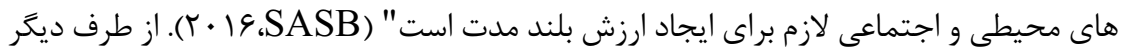

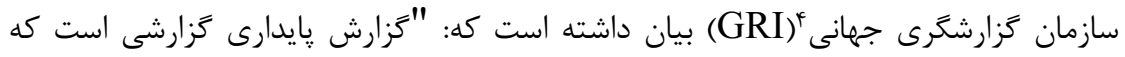

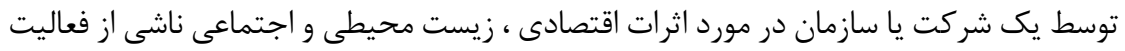

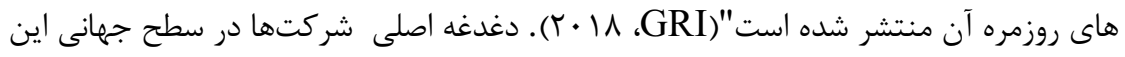

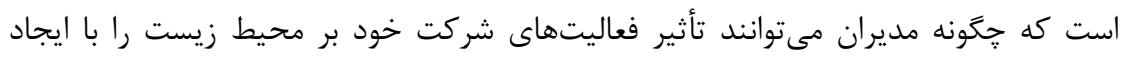

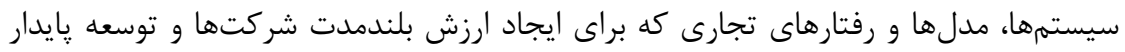

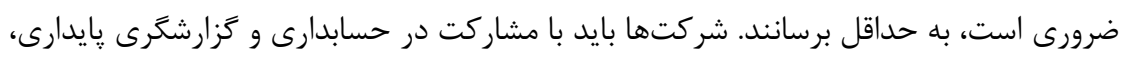

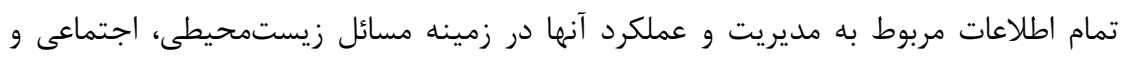

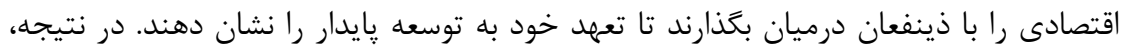

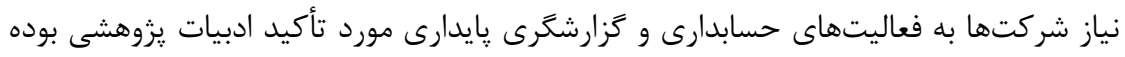

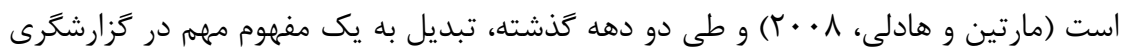

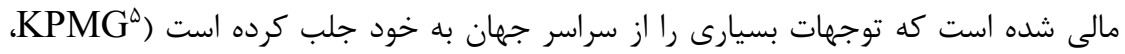

1. Theory of planned behaviour

2. Sustainability Management

3. Sustainability Accounting Standards Board

4. Global Reporting Initiative • . بكى يـىإجى يكى از بزركتر ين شركتهاى خدماتى مشاوره مالى، ماليات و حسابرسى در جهان است. 
حسابدارى و كزارشكرى يايدارى عمدتاً به فرآيندى مربوط مىشود كه سازمانها از طريق آن

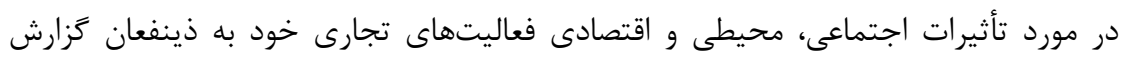

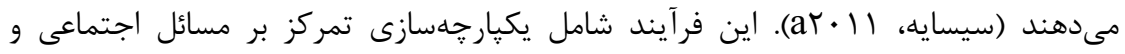

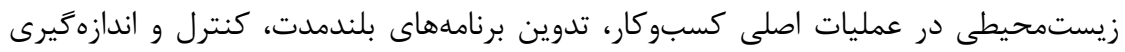

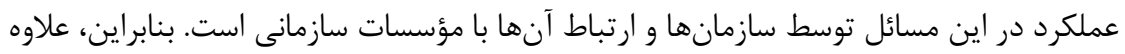

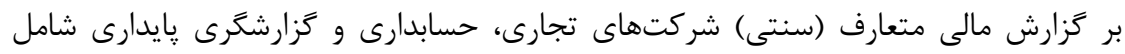

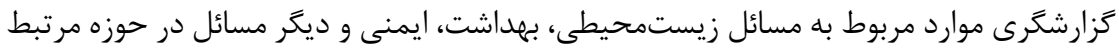

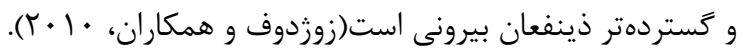

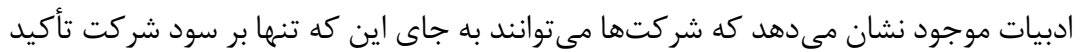

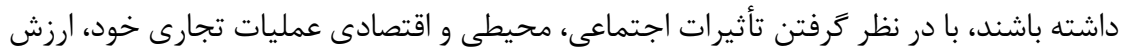

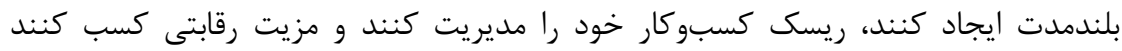

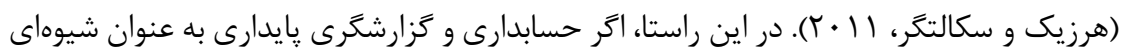
فرض شود كه در آن شركتها نيازمندى هاى بايدارى را به منظور قابل اندازه

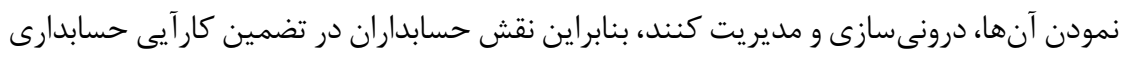

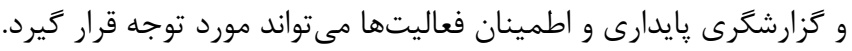

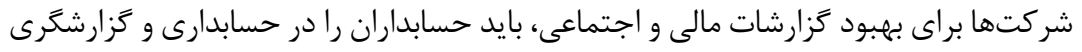

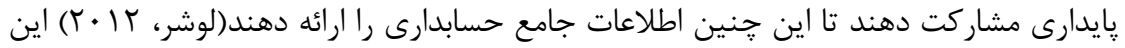

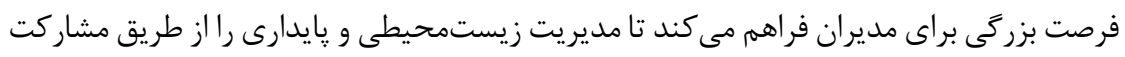

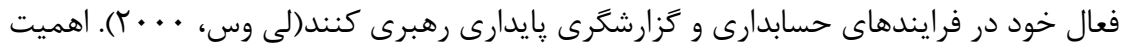

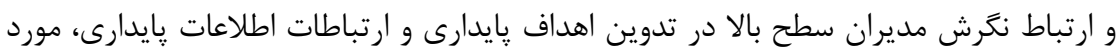

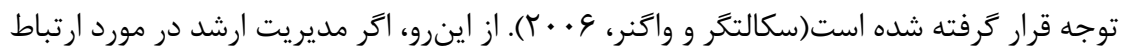

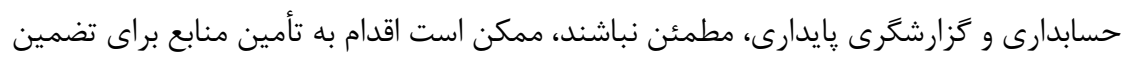

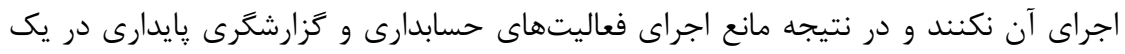

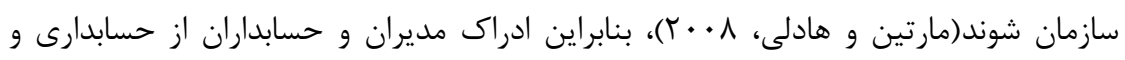

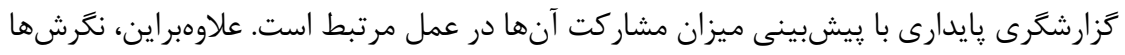

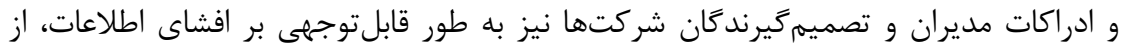

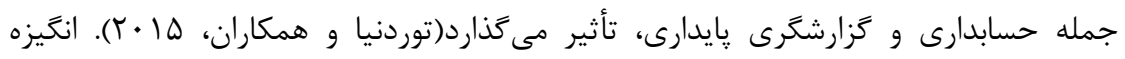

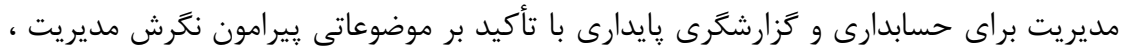

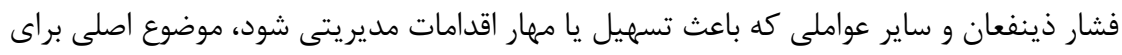
تحقيقات اجتماعى و زيست محيطى است. تحقيقات مربوط به نكرش تصميم گيرندكان نسبت 
به كزارش هاى اجتماعى و زيست محيطى حاكى از آن است كه اكثر حسابداران و مديران ارشد

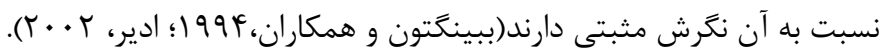

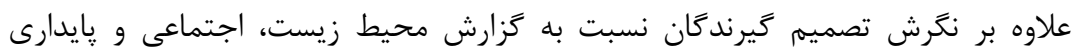

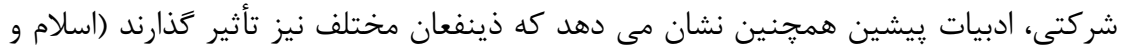

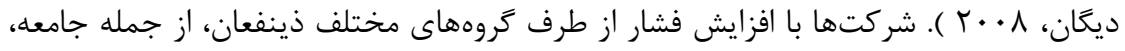

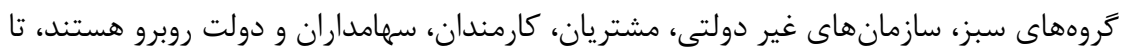

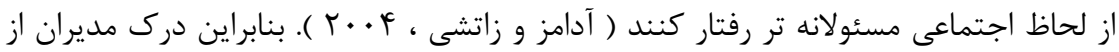

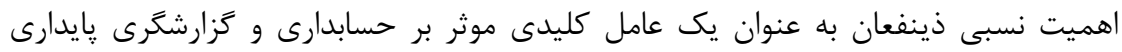

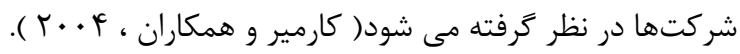

D نظريه رفتار برنامه ريزى شده (TPB)

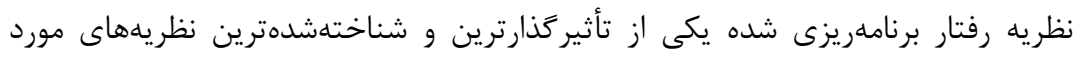
استفاده در يزوهشهاى روانشناسى براى ييشبينى و توضيح رفتار انسان است. نظريه رفتار برنام رنامه

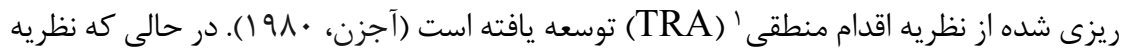

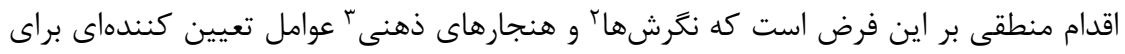

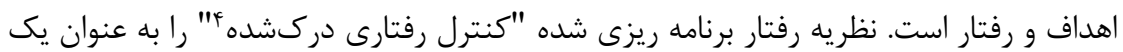

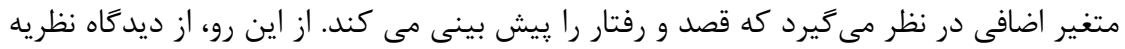

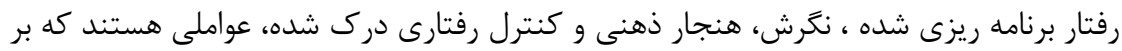

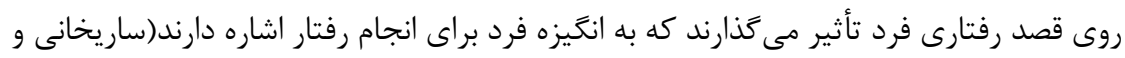

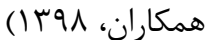
آجزن (1991) نكرش را بدين معنى كه فرد به جه ميزان يك ردان رفتار ران را مطلوب يا نامطلوب

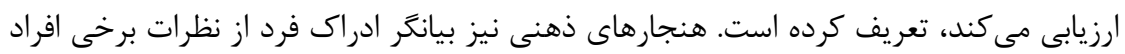

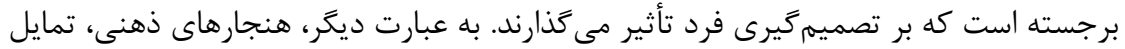

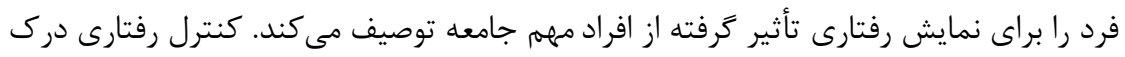

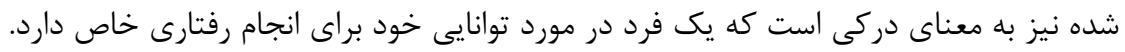

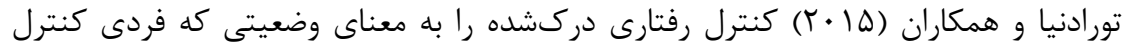
كاملى بر انجام يك رفتار را ندارد، بيان نمودهاند.

1. Theory of Reasoned Action

2. Attitude

3. Subjective norm

${ }^{4}$. Perceived Behavioral Control 


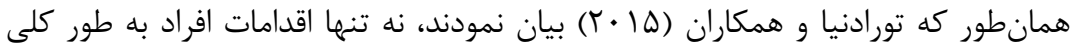

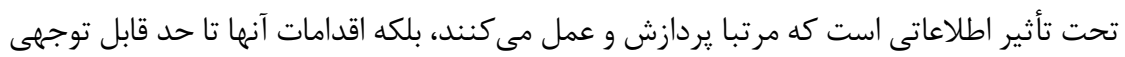

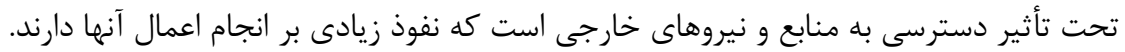

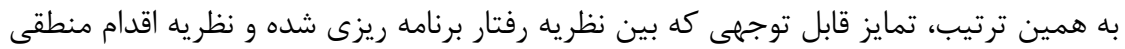

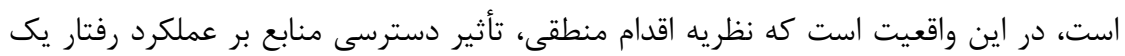
فرد را در نظر نمى

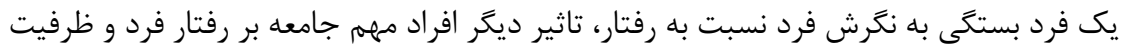

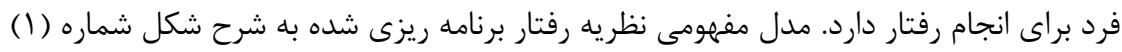
مى باشد.

شكل شماره |- نظريه رفتار برنامه ريزى شده (منبع: اجزن، 1991)

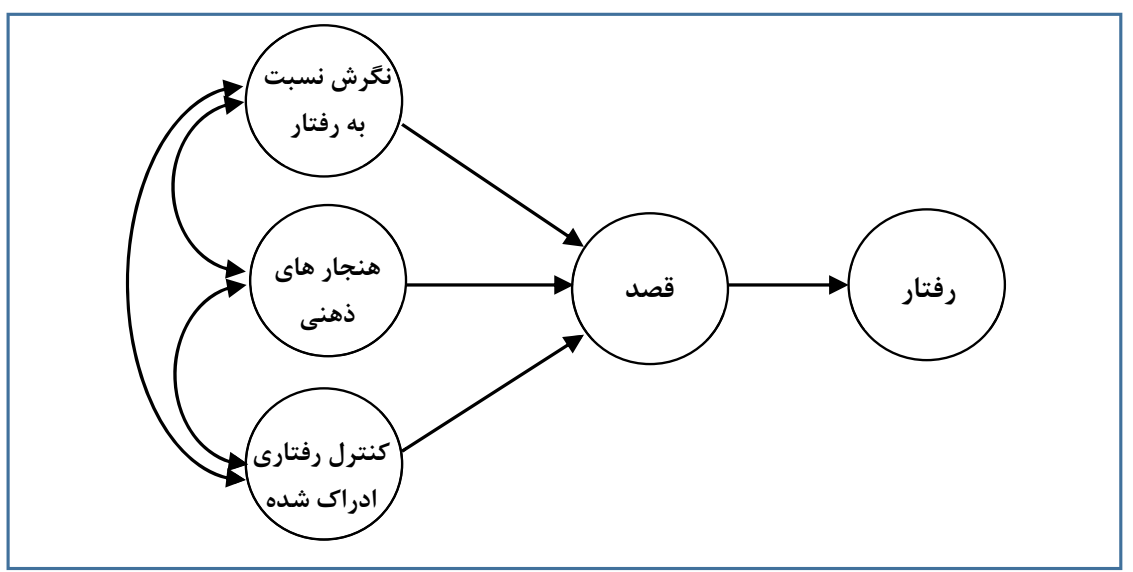

تئورى رفتار برنامه ريزى شده، نظريه اى است كه جار جوبى براى گسترش درك افراد از نيت

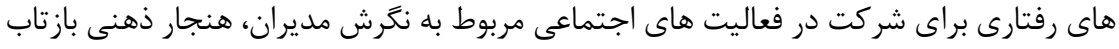

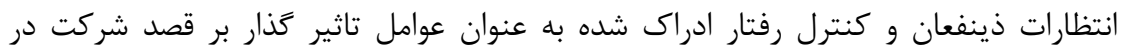

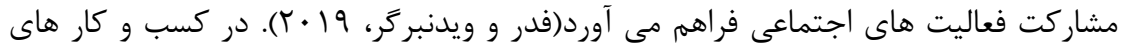

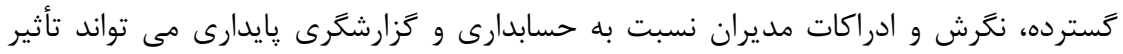

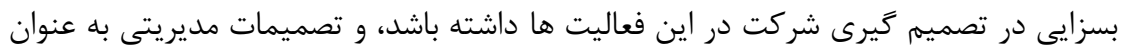

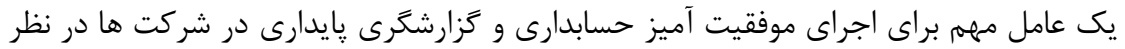
كرفته مى شود(يوندويل و همكاران، با • ()). 
بك و اجزن(1991) مدل بسط داده شده نظريه رفتار برنامه ريزى شده را با اضافه نمودن

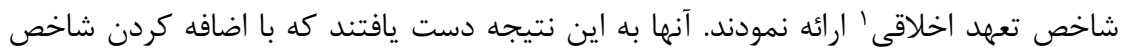

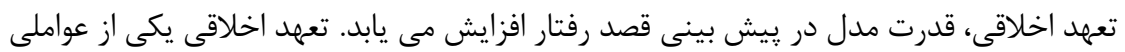

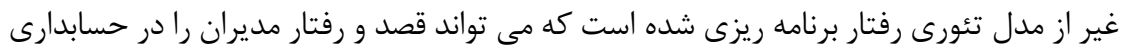

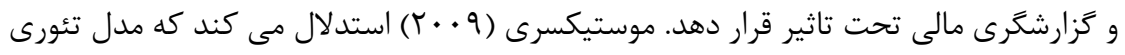

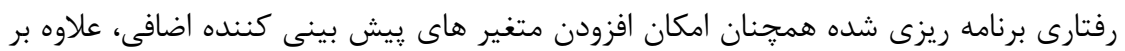

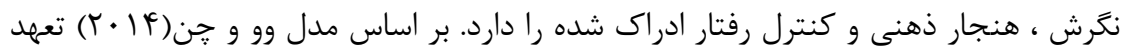

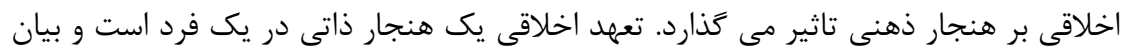

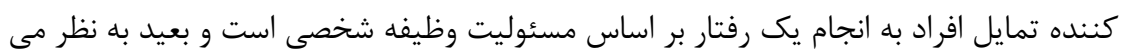
رسد كه بين ديكران مشترك باشد. در واقع رفتار، با قصد و نيتى شروع مى شى شود كه پِيش زمينه

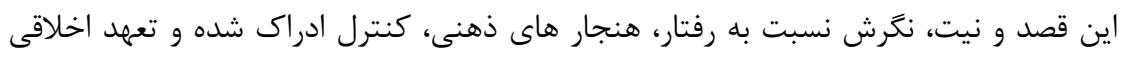

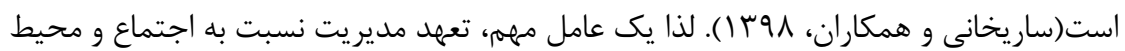
زيست است. هرجه مديران اهميت بيشترى نسبت به جامعه و محيط زيست قائل باشند، احتمالا

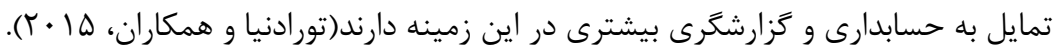

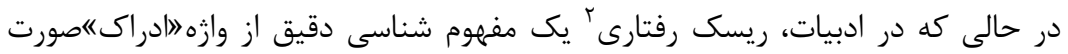

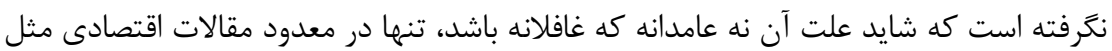

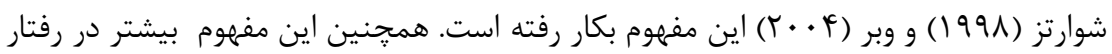

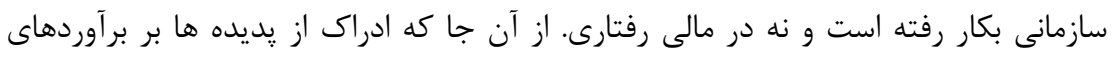

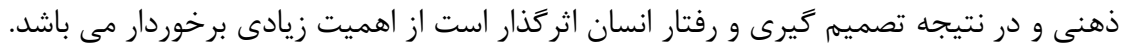

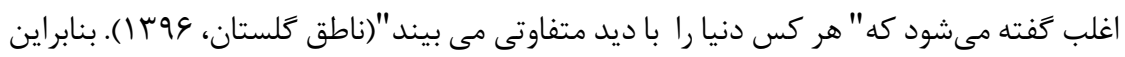

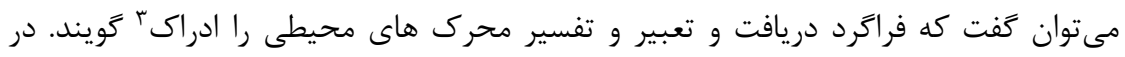

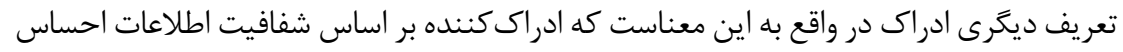

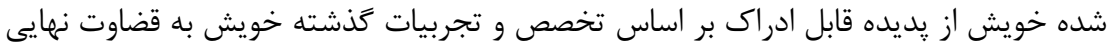

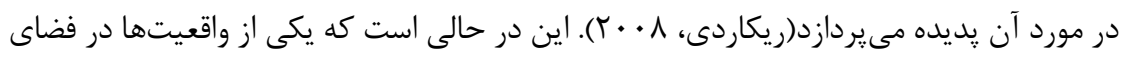

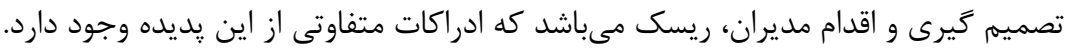

1. Ethical Commitment

2. Behavioral risk

3. Perception 
از دهه • •199 به منظور توضيح رفتار مصرف كنندكان، نظريه ادرك ريسك' مورد استفاده

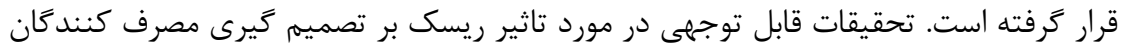

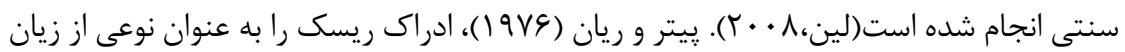

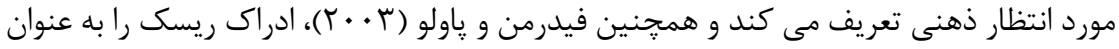

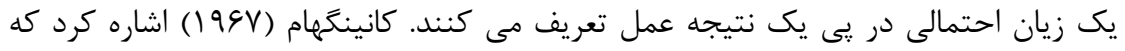
ريسك ادراك شده، ميزان زيان بالقوه اى (يعنى آنجه كه در معرض خطر است است است كه از نتايج

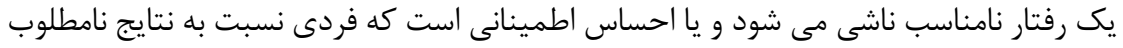

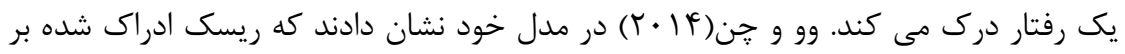

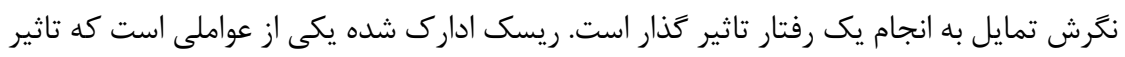

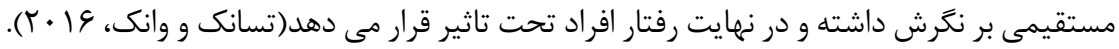

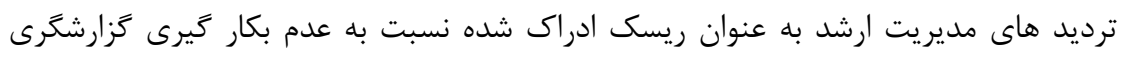

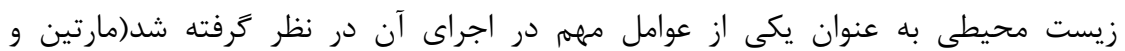

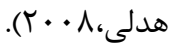

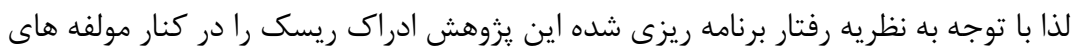

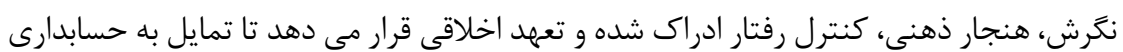

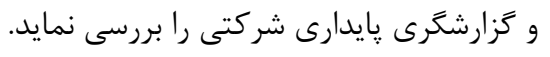

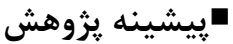

تاكنون نظريه رفتار برنامه ريزى شده در مورد بسيارى از رفتارهاى مرتبط بار با مسئوليت

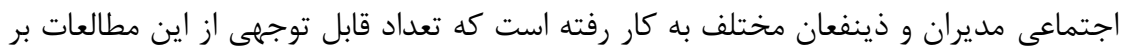

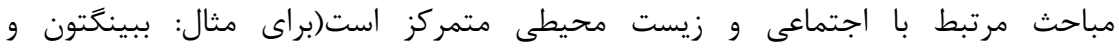

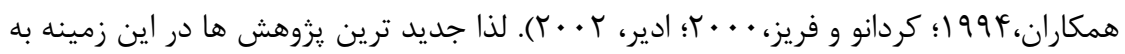

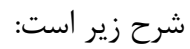

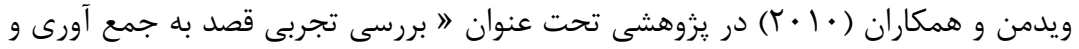

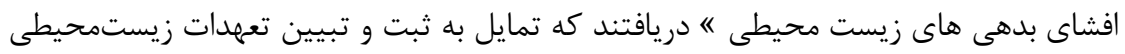
توسط مديران مالى به طور مثبتى با هنجارهاى ذهنى آنها و كنترل رفتارى دركى شده مرتبط

سايمونسن و ونستاٍ(1) (1)، تعهدات اخلاقى شركت ها را در ارائه منصفانه كزارشكرى

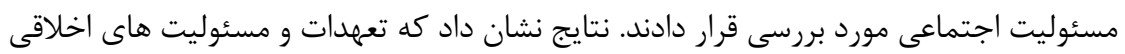

${ }^{1}$. Perceived Risk 
تاثير مثبتى بر كزارشكرى مسئوليت اجتماعى دارد و صفات و شخصيت انسان، رايج ترين ديدكاه

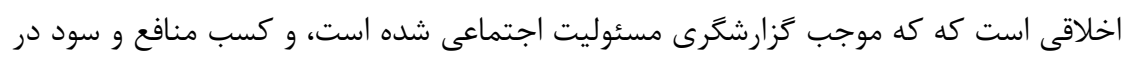

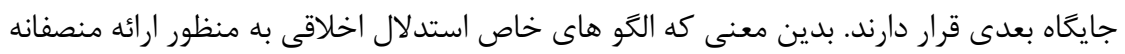

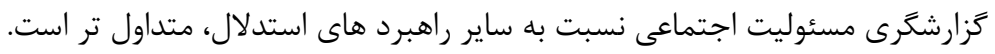

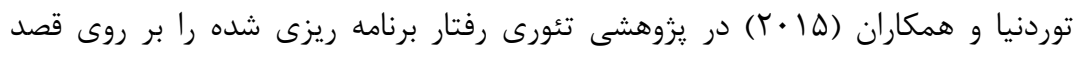

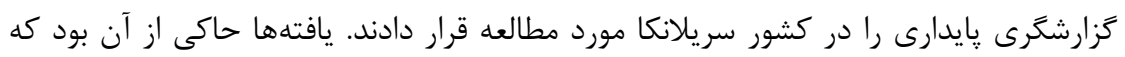

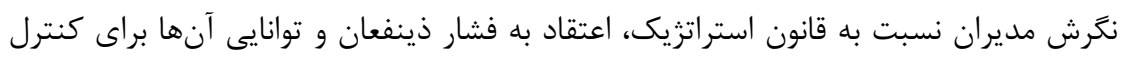

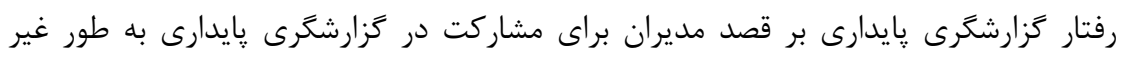

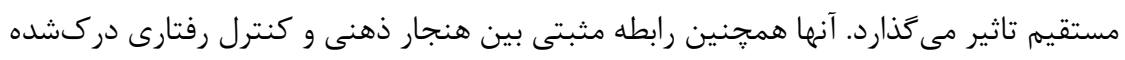

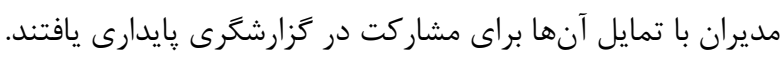

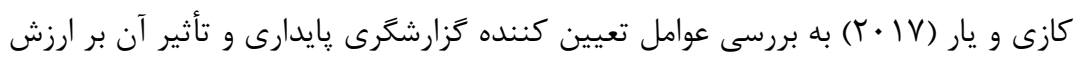

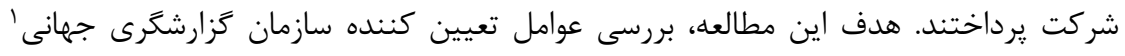

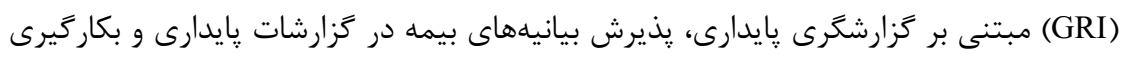

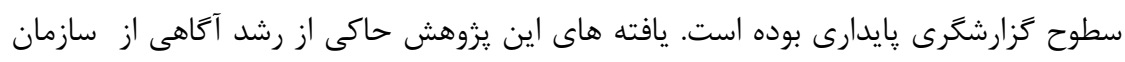

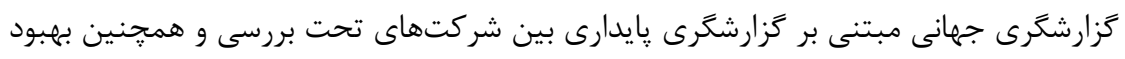

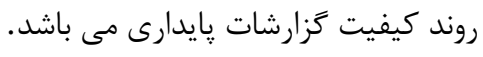

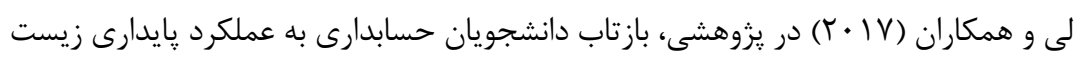

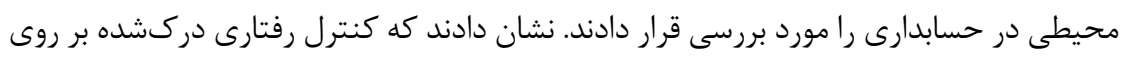

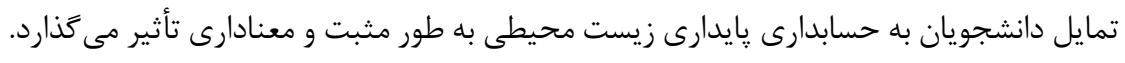

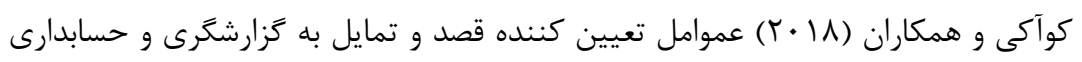

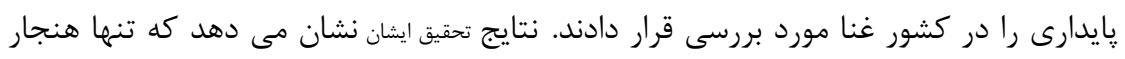

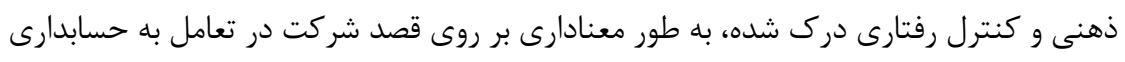

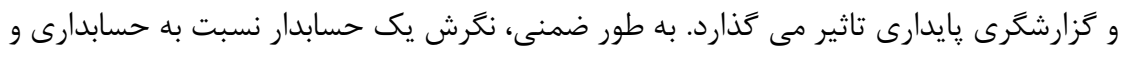

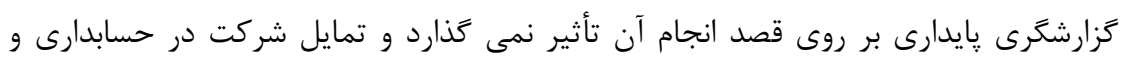

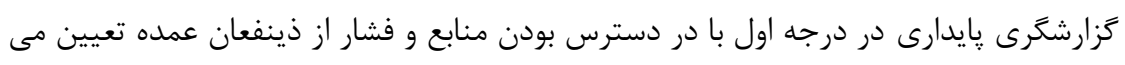

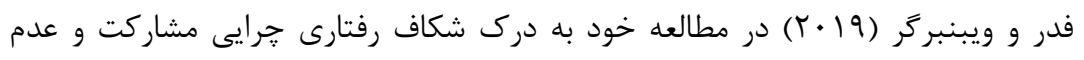

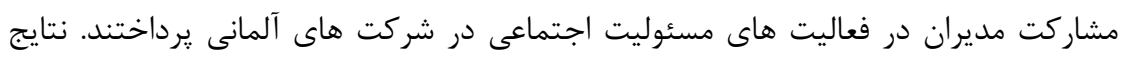

\footnotetext{
1. Global Reporting Initiative
} 
ايشان نشان داد كه نكرش تاثير زيادى بر تمايل مديران بر انجام فعاليت هاى مرتبط با مسئوليت

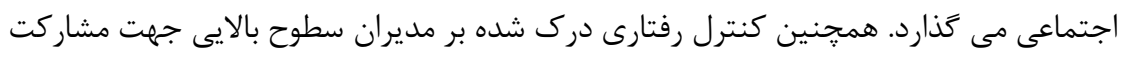

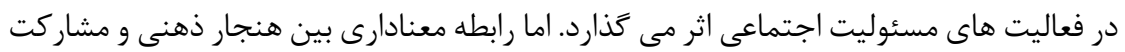
در مسئوليت اجتماعى مشاهده نشد.

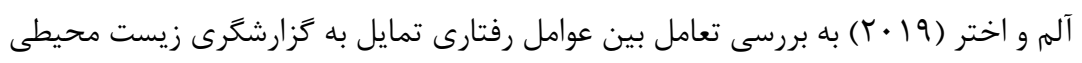
يرداختند. هدف اين مطالعه، جستجوى عوامل برجسته تعيين كننده قصد افشاى إنى اطنلاعات

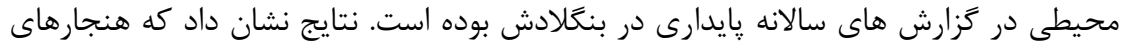

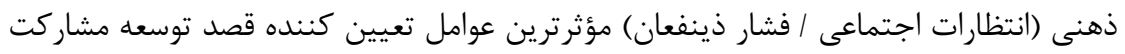

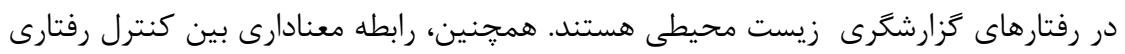

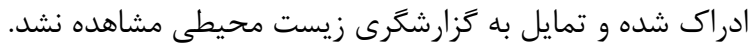

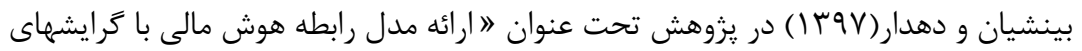

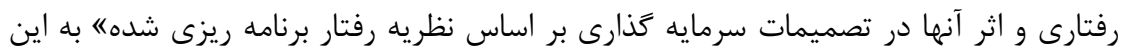

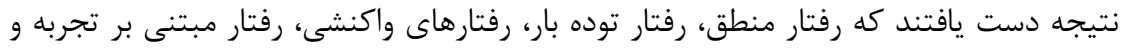

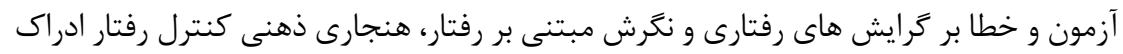

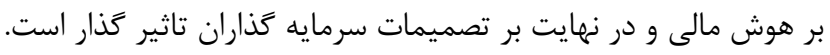

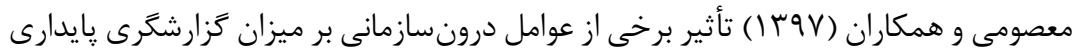

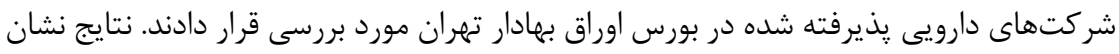

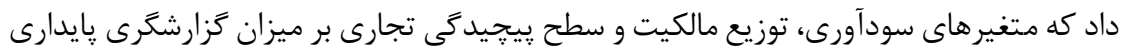

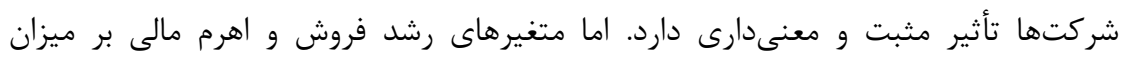

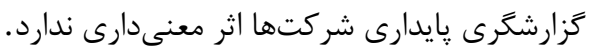

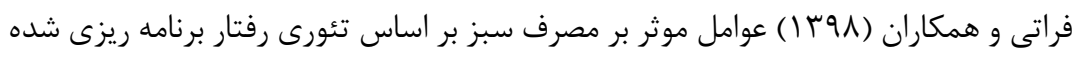

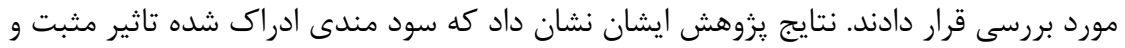

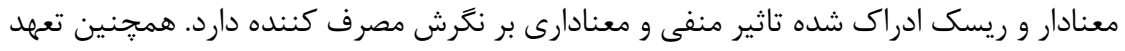

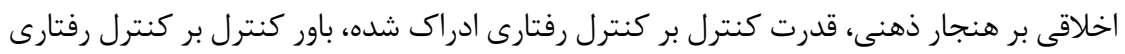

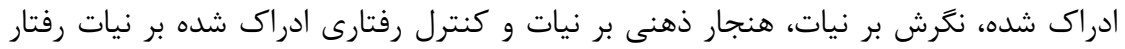
واقعى مصرف كننده سبز تاثير معنادارى دارد.

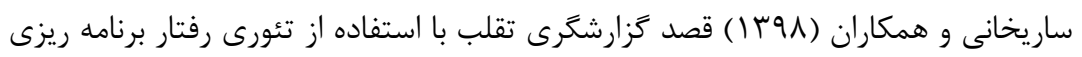

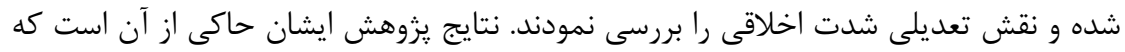

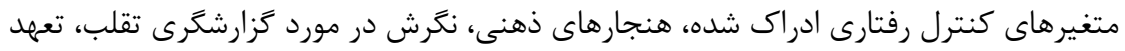


اخلاقى و تعهد حرفهاى داراى تأثير مثبتى بر قصد كزارشكرى تقلب هستند و شدت اخلاقى تأثير متغيرهاى هنجارهاى ذهنى و تعهد حرفهاى بر قصد كزارشكرى تقلب را تعديل مى كند. با توجه به بررسى بيشينه يزوهش، مطالعات اندكى در زمينه عوامل موثر بر اساس تئورى

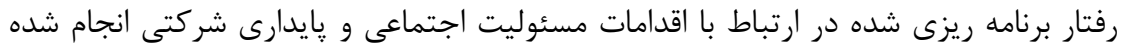

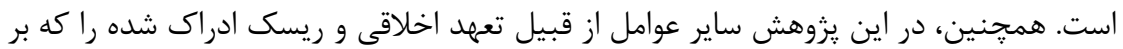
عوامل نظريه رفتار برنامه ريزى شده تاثير كذار است، در ارتباط بار با تمايل به حسابل حسابدارى و

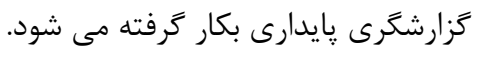

\section{ب-فرضيههاى تحقيق}

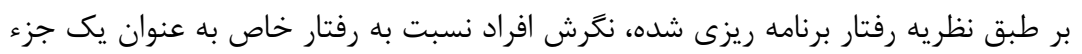

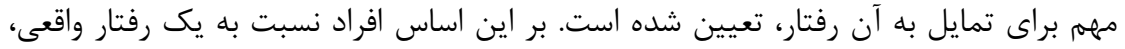

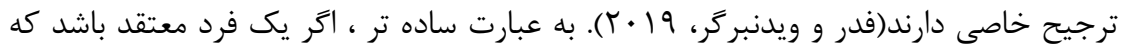

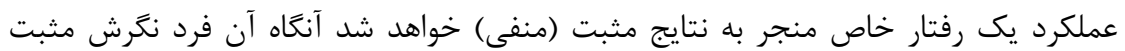

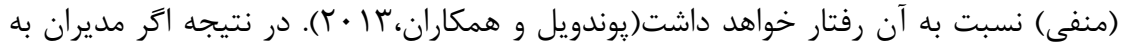

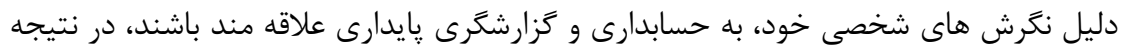

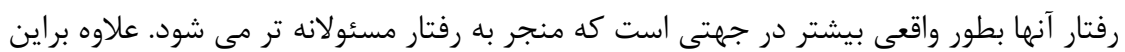

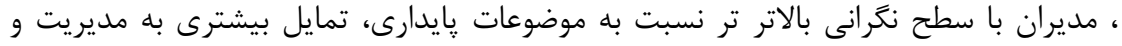

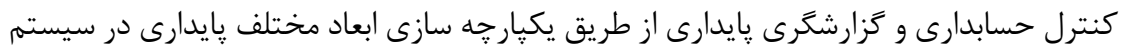

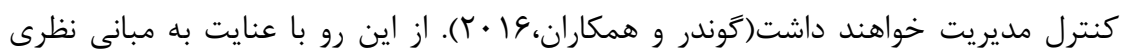
فرضيه اول يزوهش به شرح زير تدوين مى كردئ

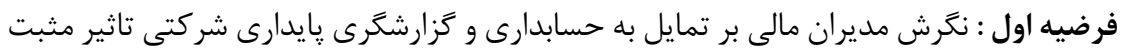

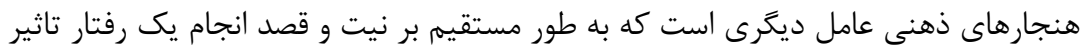

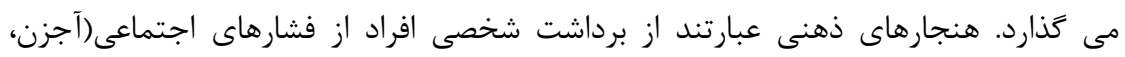

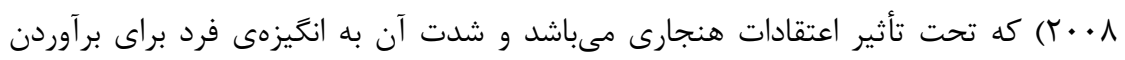

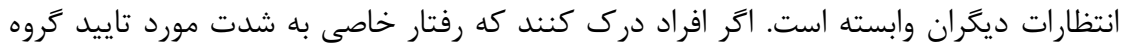

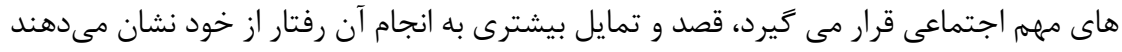

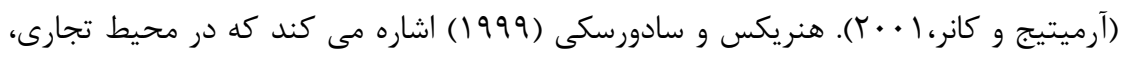
فشار اجتماعى بر تصميم كيرى مديران تاثير كذار است. در نتيجه در زمينه مسئوليت اجتماعى و وايدارى شركتى، ذينفعان فعلى و بالقوه منبع فشار در محيط تجارى هستند. در نهايت، فشار 
اجتماعى كه از طريق حداقل هنجار هاى ذينفعان بدست آمده و توسط مديران درك شده است،

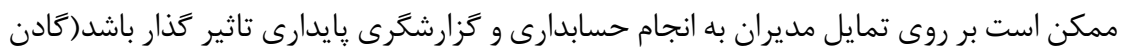

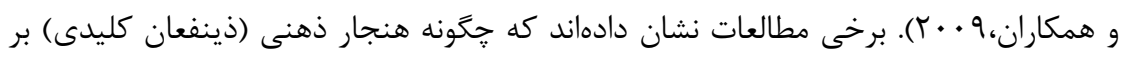

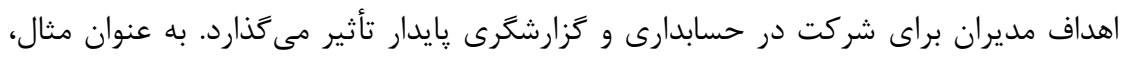

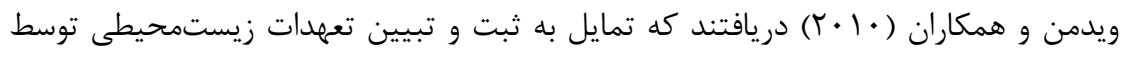

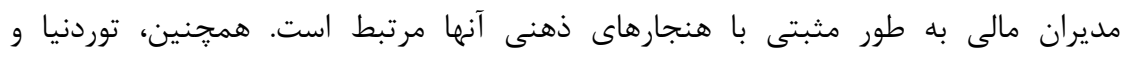

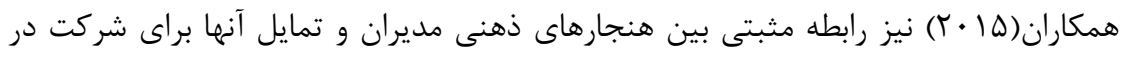

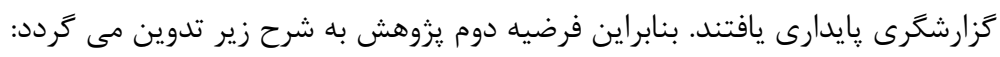

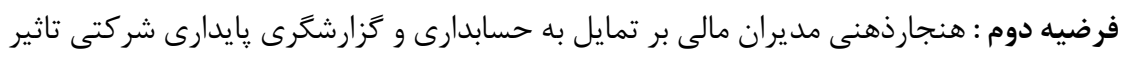

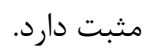

كنترل رفتارى درك شده ، به سهولت و يا دشوارى درك انجام يك رفتار خاص (آجزن، (99 (199 )

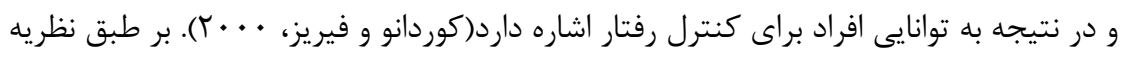

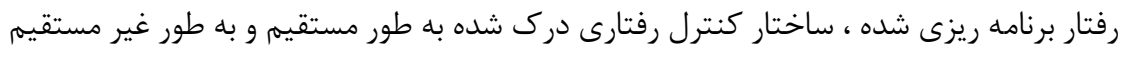

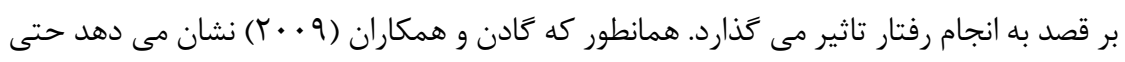

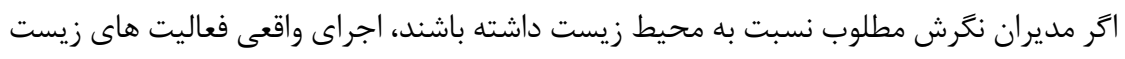

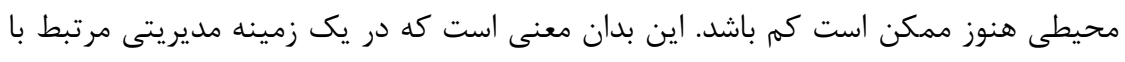

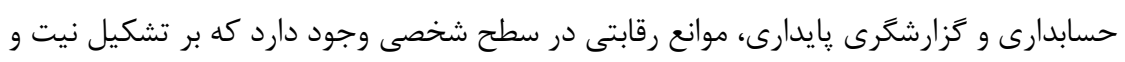

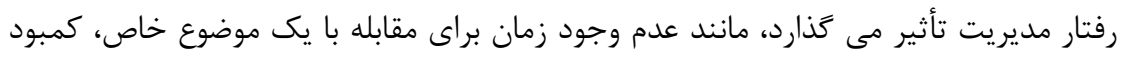

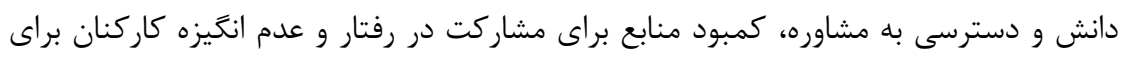

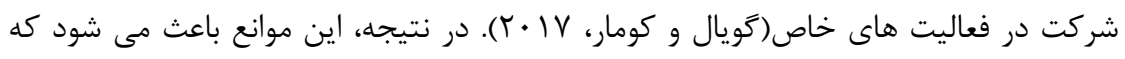

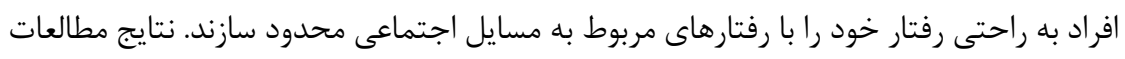

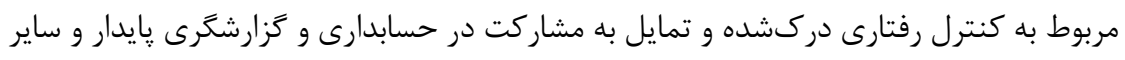

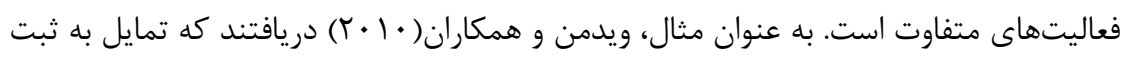

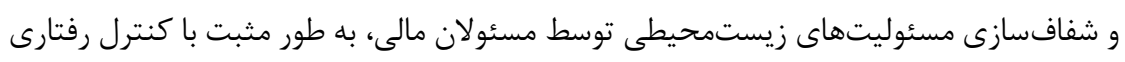

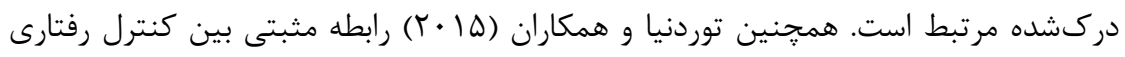

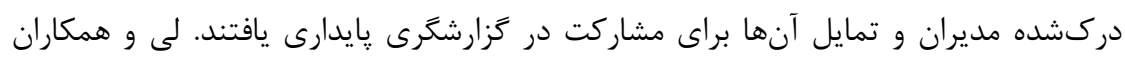

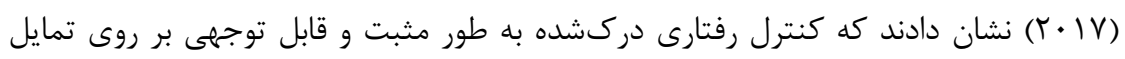

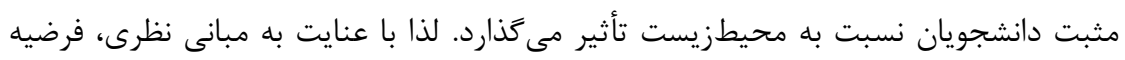
سوم يزوهش به شرح زير است: 
فرضيه سوم : كنترل رفتارى ادراى شده مديران مالى بر تمايل به حسابدارى و كَزارشكرى : بايدارى شركتى تاثير مثبت دارد.

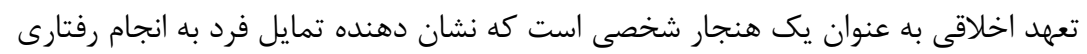

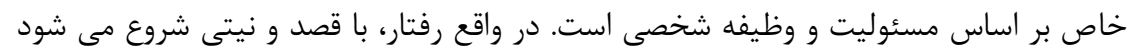

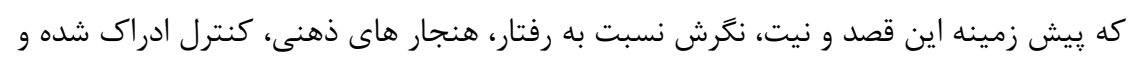

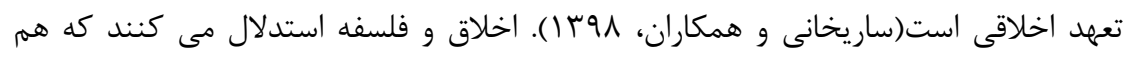

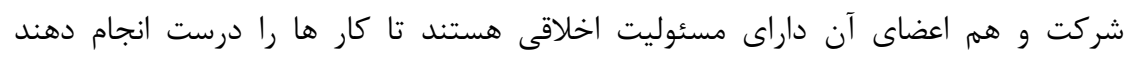

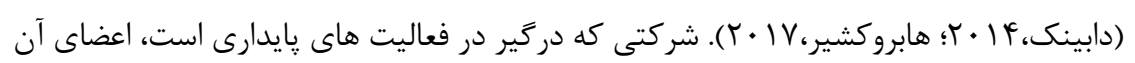

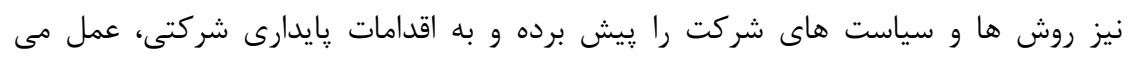

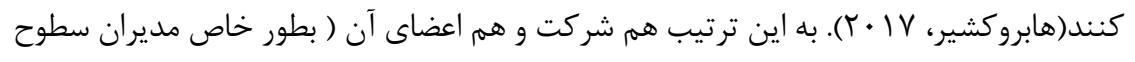

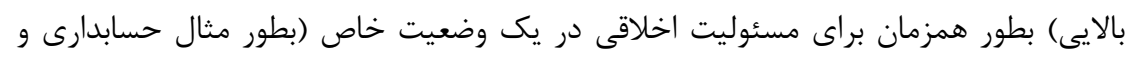

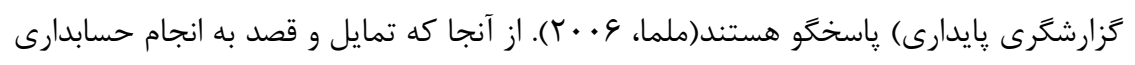

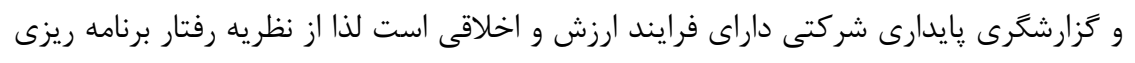

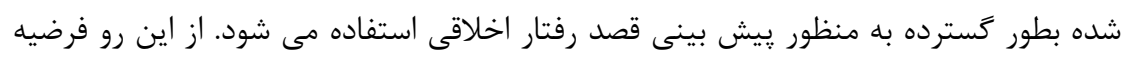
جهارم يزوهش به شرح زير است: فرضيه جهارم : تعهد اخلاقى مديران مالى بر تمايل به حسابدارى و كزارشكَرى يايدارى شركتى تاثير مثبت دارد.

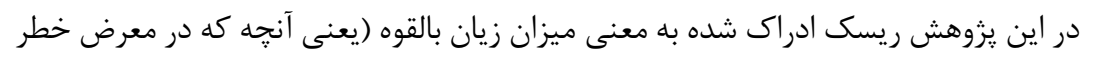

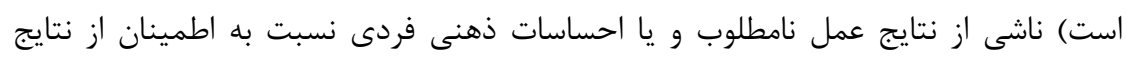

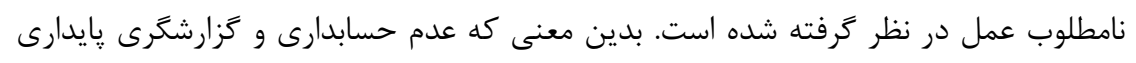

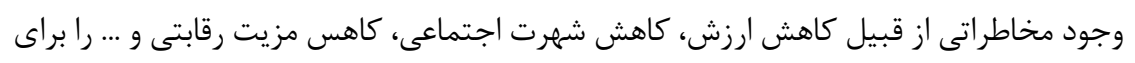

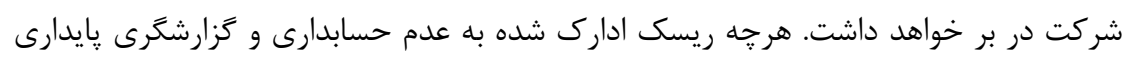

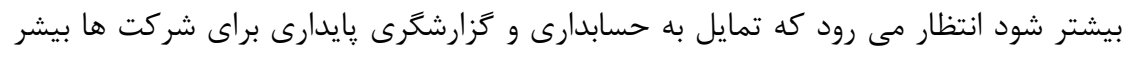

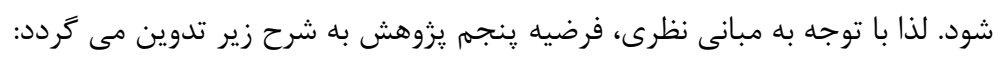

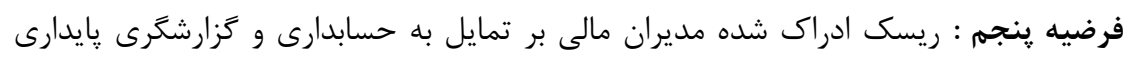
شركتى تاثير مثبت دارد.

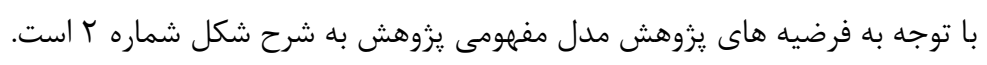




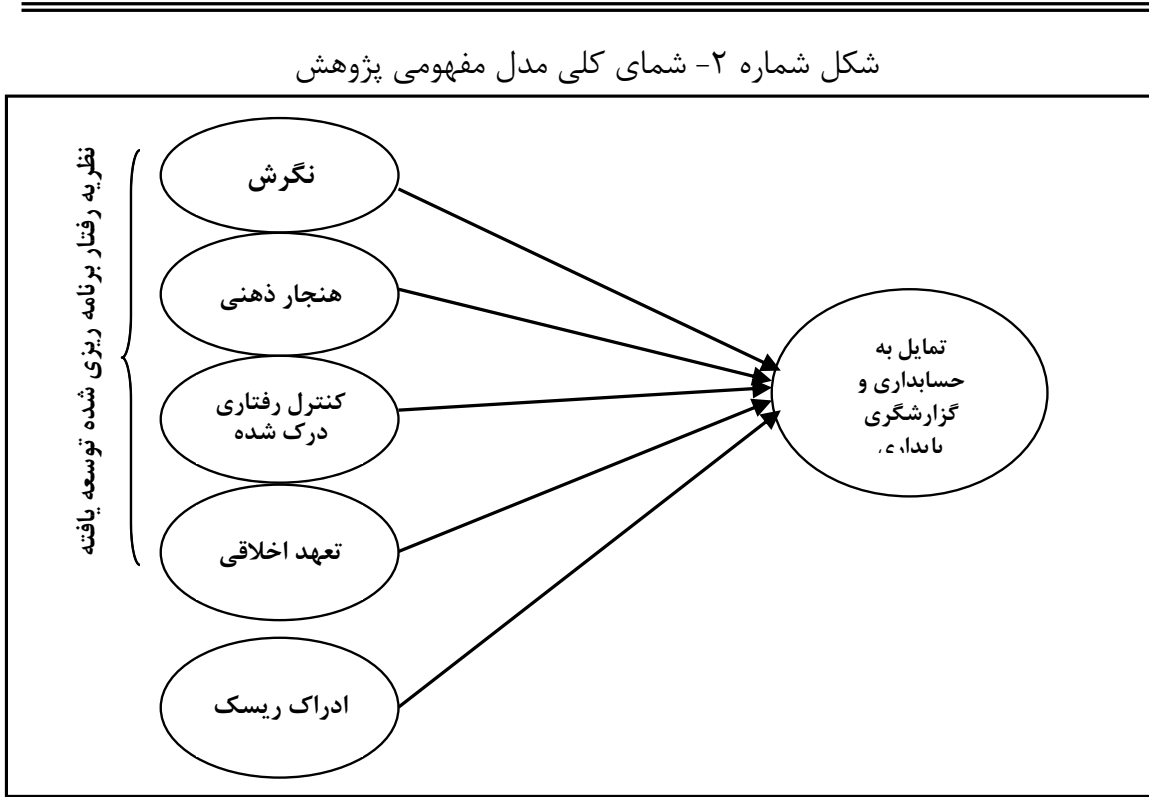

\section{F}

يزوهش حاضر، توصيفى از نوع بيمايشى است و دادهها از طريق مجموعهاى از برسشنامهها

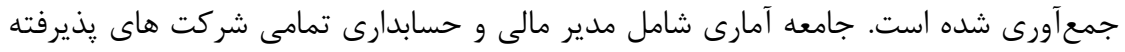

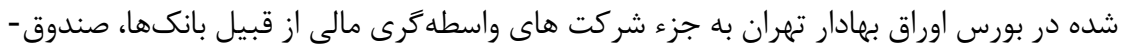

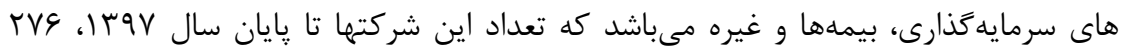

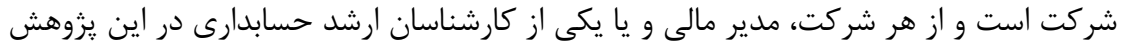

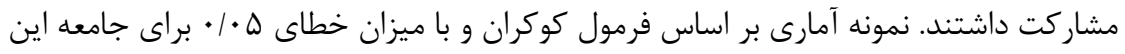

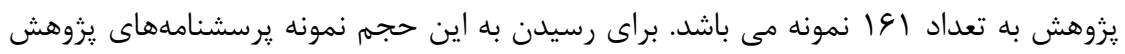

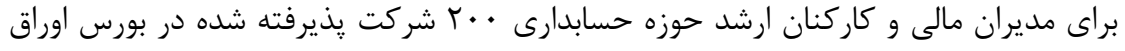

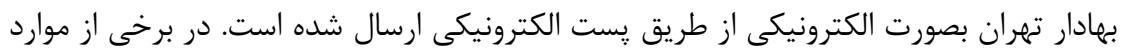

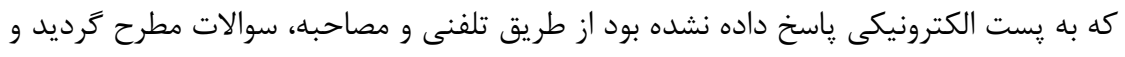

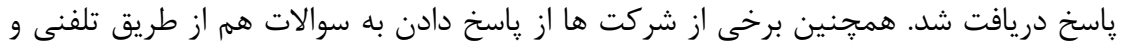

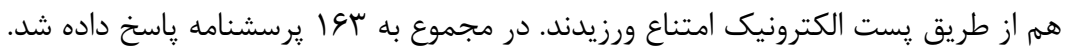

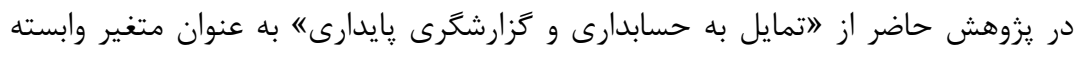

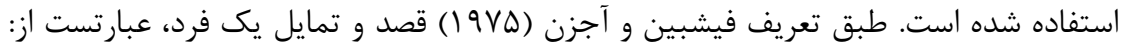

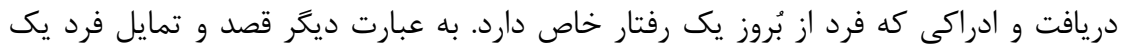


موقعيت ذهنى و احتمالى مىباشد كه بين فرد با عمل وى ارتباط برقرار مى كند (كيى و رامايا،

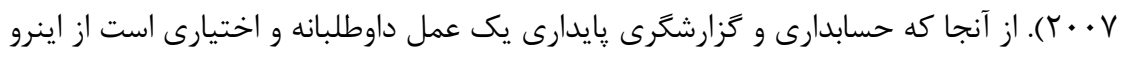

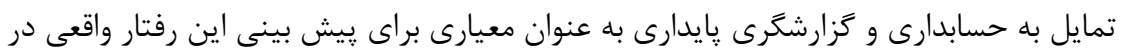

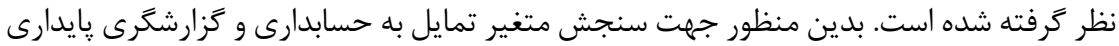

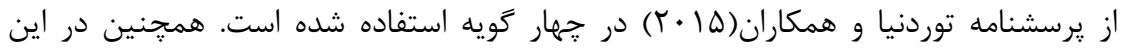

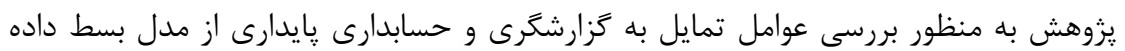

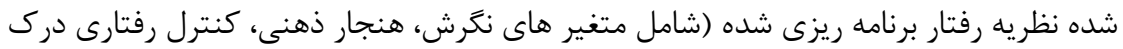

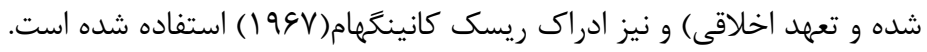

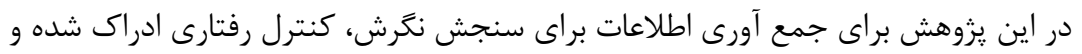

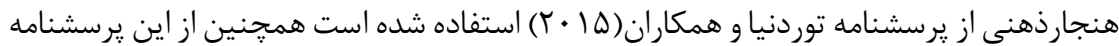

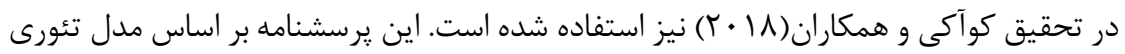

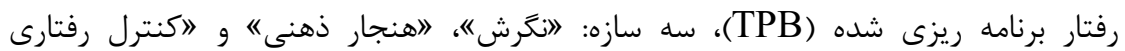

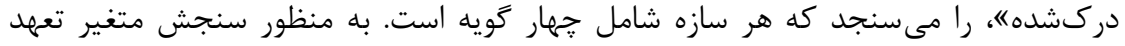

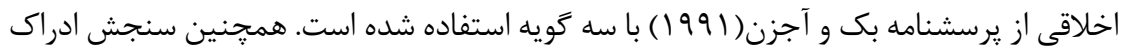

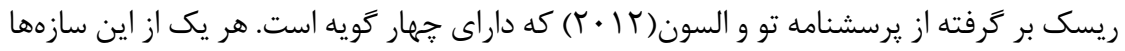
بر اساس مقياس ينج طبقه اى ليكرت با شاخصهاى جندكانه توصيف شده است. از ياسخدهندكان خواسته شد ميزان موافقت/مخالفت خود را بر اساس مقياس ليكرت با ينج امتياز

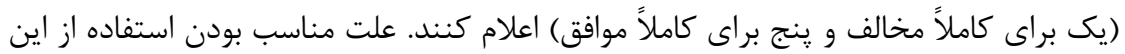
يرسشنامه ها در مطالعه حاضر اين بود كه يرسش ها بر اساس بسيارى از يرسشنامهای مإى موجود،

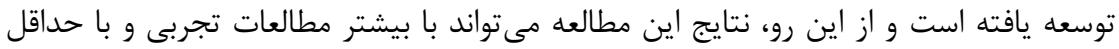

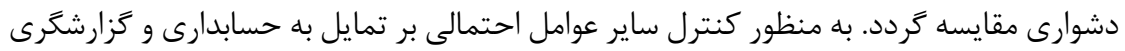

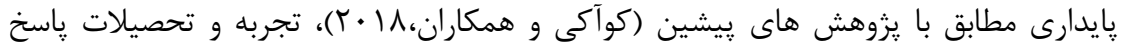

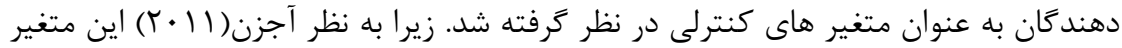

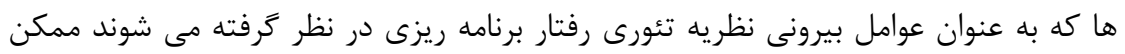

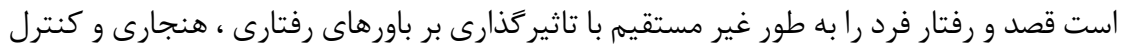

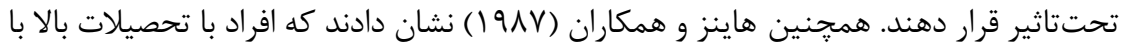

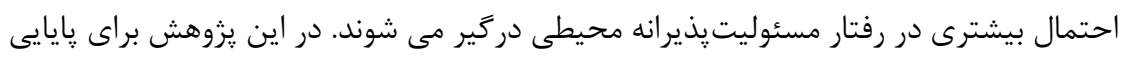

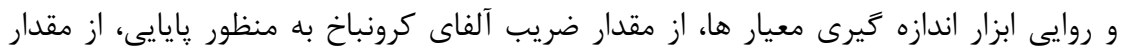

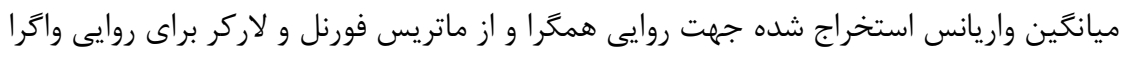
استفاده شده است. 


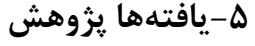

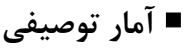

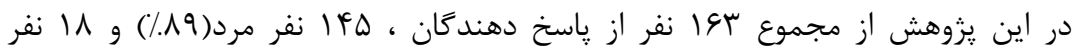

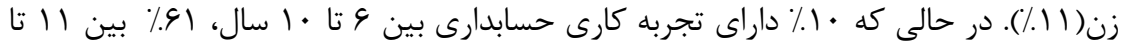

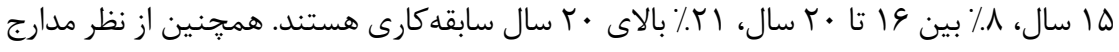

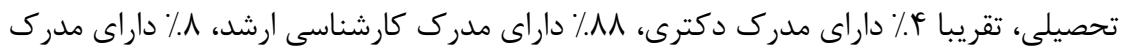
كارشناسى مى باشند.

\begin{tabular}{|c|c|c|c|c|c|c|}
\hline جولنى & كشيدكى & انحراف استاندارد & ميانگين & 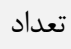 & 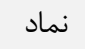 & متغير \\
\hline$-\cdot / \Delta V V$ & $-\cdot \mid G T F$ & I/TIAT & r/r/9. & 194 & INT & 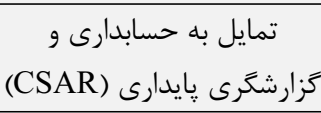 \\
\hline.$- / 9 V r$ & . AqV &.$/ 9 \wedge \Delta T$ & T/VQTI & 194 & ATT & نكرش \\
\hline.$- / 1 \& q$ & $.1 .1 \mathrm{~V}$ & $1 / .4 \mu 1$ & $r / .901$ & 194 & SN & هنجارذهنى \\
\hline .1194 & $\cdot / / V r$ & $\cdot / V 11 \cdot$ & T/Q人૬र & 194 & $\mathrm{BC}$ & كنترل رفتارى ادراك شده \\
\hline$\cdot / T V F$ & $-\cdot / \cdot+\wedge$ & . 11911 & T/VTG. & 194 & EC & تعهد اخلاقى \\
\hline.$- / 49 \Delta$ & $-\cdot / V \wedge 9$ & $1 / \cdot r \cdot r$ & r/.GFF & 194 & $\mathrm{RP}$ & ادراى ريسك \\
\hline
\end{tabular}

جدول شماره (1) آمار توصيفى متغيرها (تمايل به اجراى حسابدارى و كزارش كرى برى بايدار،

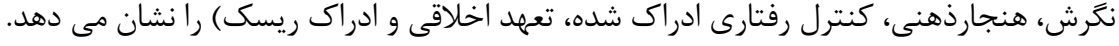

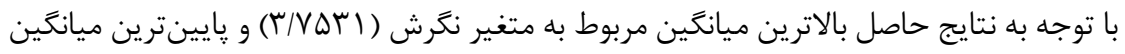

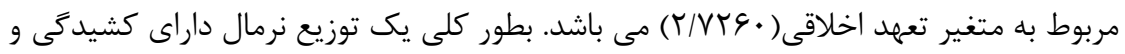

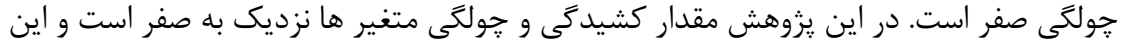
شاخص ها بيانكر اين موضوع مى باشد كه متغير داراى توزيع متقارن بوده توزيع آنها شبيه نرمال

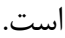

\section{קايايى و روايى ابزار اندازه كيرى}

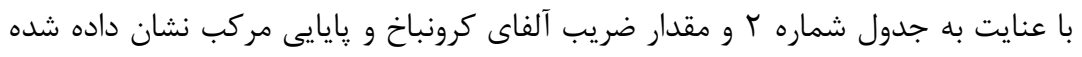

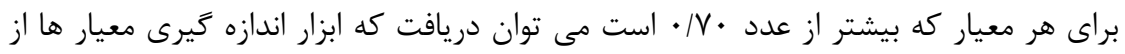

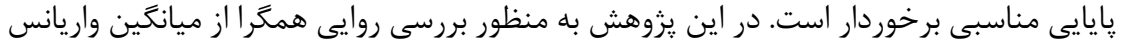

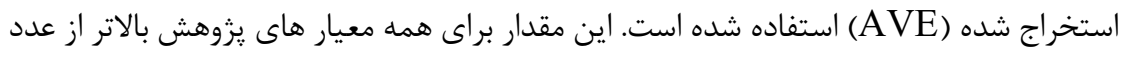

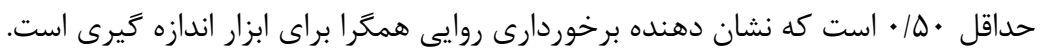



امين و دكترعبداله زاده، تاثير نظريه رفتار برنامه ريزى شده، تعهد اخلاقى و ادراك ريسك بر تمايل... جدول شماره - نتايج روايى همخرا و پايايى ابزار اندازه كيرى

\begin{tabular}{|c|c|c|c|c|}
\hline ميانخين واريانس استخراج & مركبي & ضريب آلفاى & تعداد & متغيرها \\
\hline $.19 \cdot 1$ & $.19 V r$ &.$/ 984$ & i & تمايل به CSAR \\
\hline .1119 &.$/ 9 \& V$ &.$/ 970$ & f & ن نخرش \\
\hline$\cdot / 1 \cdot r$ & $.194 T$ &.$/ 911$ & f & هنجارذهنى \\
\hline .1911 & •/Vq4 & $\cdot / V \& q$ & i & كنترل رفتارى ادراى شده \\
\hline - NRG & . /А9 & - IATT & r & تعهد اخلاقى \\
\hline$\cdot \mid \Lambda \Delta F$ & .1909 &.$/ 945$ & f & ادراك ريسك \\
\hline
\end{tabular}

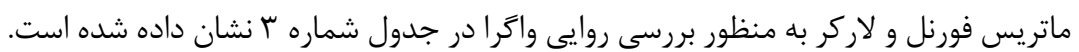

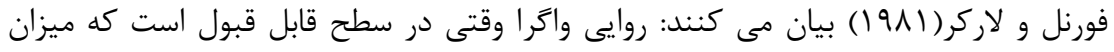

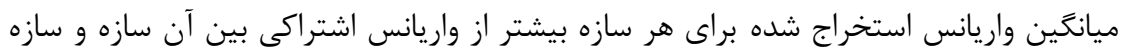

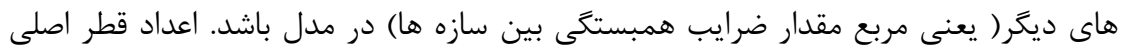

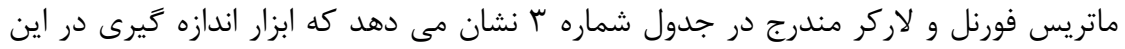

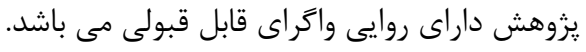

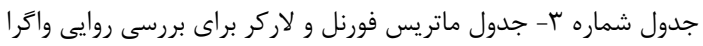

\begin{tabular}{|c|c|c|c|c|c|c|c|c|}
\hline$\wedge$ & V & 4 & $\Delta$ & f & r & r & 1 & 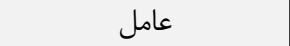 \\
\hline & & & & & & &.$/ 949$ & تمايل به CSAR \\
\hline & & & & & & $\cdot 19 \cdot \Delta$ & . /VTG & ن تخرش \\
\hline & & & & &.$/ 19 \Delta$ & .199. & - 19Dr & هنجارذذهنى \\
\hline & & & & -/VAr & . IEMF & $\cdot / \Delta \mathrm{V} \cdot$ & $\cdot / M V I$ & كنترل رفتارى ادراك شده \\
\hline & & & $\cdot / \wedge \Delta \wedge$ & $\cdot 10 \cdot 9$ & $\cdot 19 \cdot \Delta$ & $\cdot|49|$ & $.19 V Y$ & تعهد اخلاقى \\
\hline & &.$/ 9 \mathrm{rF}$ & $\cdot \mid V Y I$ & - /DHA & $\cdot / \Delta \vee \wedge$ & $\cdot / \Delta \Delta r$ & $\cdot / V T \cdot$ & ادراك ريسك \\
\hline & 1 & $-\cdot / 19$. & $-\cdot / r \Delta \mid$ &.$- \cdot \cdot 91$ &.$- / 4 m t^{-1}$ & $-\cdot / 1 \mathrm{VT}$ & $-.119 \mathrm{~V}$ & تحصيلات \\
\hline 1 & $-\cdot / T V D$ & $\cdot|\Delta \wedge|$ & . 1949 & $\cdot / T \wedge \&$ & . Mtr & $\cdot / F V \cdot$ & $\cdot / F \Delta F$ & تجربه \\
\hline
\end{tabular}

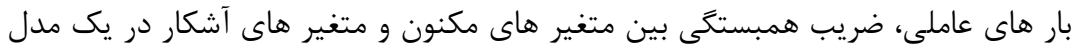

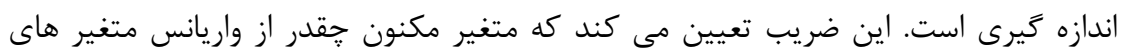

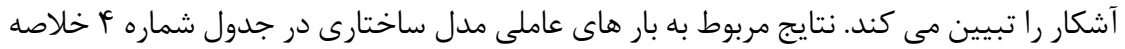

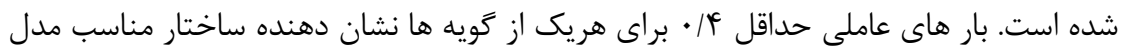

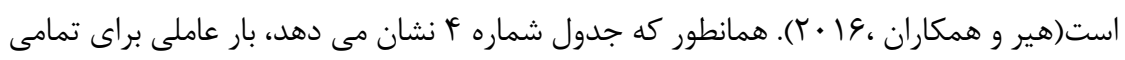

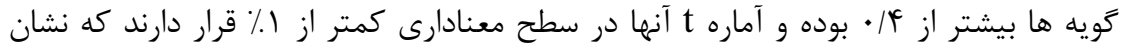
دهنده ساختار مناسب مدل است. 


\begin{tabular}{|c|c|c|c|c|}
\hline \multicolumn{5}{|c|}{ جدول شماره F - - نتايج بار عاملى مدل ساختارى } \\
\hline سطح معنادارى & t & انحراف از إندارد & ضريب مسير & مسير \\
\hline$\bullet /+\bullet$ & $r \cdot r / 999$ & $\cdot 1 \cdot \cdot \Delta$ & $.199 \wedge$ & تمايل -> گويه 1 \\
\hline$\bullet 1+\bullet$ & $\Lambda T / V I S$ & $\cdot 1 \cdot 11$ &.$/ 9 F F$ & |تمايل ->> گويه r \\
\hline 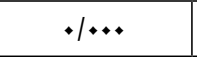 & $V T / I F$ & $\cdot 1 \cdot 11$ &.$/ 9 \Delta F$ & |تمايل ->> گويه r \\
\hline$\bullet 1+\cdots$ & $q V / q \cdot r$ & $.1 \cdot 1 \mathrm{f}$ & .1941 & |تمايل ->> تويه F| \\
\hline$\bullet 1+\cdots$ & fl/rmb & $\cdot \mid \cdot Y 1$ & $\cdot \mid \Lambda V^{\prime}$ & نغرش ->>ويهد \\
\hline$\bullet 1+\cdots$ & FI/VTV & $\cdot 1 \cdot r \cdot$ & $\cdot \operatorname{lntV}$ & نخرش ->>ويه \\
\hline$\bullet /+\bullet$ & $\Lambda \& / \vee \Delta \vee$ & $\cdot 1 \cdot 11$ & .1949 & نخرش -> گويه V \\
\hline$\cdot 1 \cdots$ & $199 / 11 \mathrm{~m}$ & $.1 \cdot .9$ & .1991 & نغرش ->>ويه1 \\
\hline$+1 \cdots$ & $\Delta r / T \Delta \Lambda$ & $\cdot 1 \cdot 11$ & . & هنجار ذهنى -> گويه9 \\
\hline$+1 \cdots$ & $r \cdot / \cdot \Delta \Lambda$ & $\cdot 1 \cdot 49$ & $\cdot 1199$ & هنجار ذهنى ->> گويه • \\
\hline$\bullet 1+\cdots$ & $V F / \Delta G D$ & $.1 \cdot 14$ & .1941 & هنجار ذهنى ->> گويه || \\
\hline$\bullet 1+\cdots$ & r & $\cdot \mid \cdot r F$ & $\cdot 11499$ & هنجار ذهنى ->> گويه || \\
\hline$+1+\cdots$ & $0 / 1 \wedge 9$ & $\cdot 1111$ & .1914 & كنترل رفتارى -> گويهس| \\
\hline$+1+\cdots$ & $G|\cdot r|$ & $.1 \cdot 99$ & $\cdot \mid \Delta \vee G$ & كنترل رفتارى -> تويه | \\
\hline$\bullet 1+\cdots$ & G/TIT &.$/ I T V$ & $\cdot|\vee 9|$ & كنترل رفتارى -> تويهها \\
\hline$\bullet 1+\cdots$ & G/FVT &.$/ I T F$ & $\cdot / \Lambda \cdot r$ & كنترل رفتارى ->> تويه 19 \\
\hline$\bullet 1+\bullet$ & IVIAFF & $.1 \cdot \hat{H V}$ & • IATV & تعهد اخلاقى ->> تويه IV \\
\hline$\bullet 1+$. & $\Delta V / V \cdot I$ & $\cdot 1 \cdot 10$ & $\cdot / \wedge \wedge \Delta$ & تعهد اخلاقى ->> گويه|| \\
\hline$+1+\cdot$ & rV/Tqr & . & $\cdot|\wedge \Delta|$ & تعهد اخلاقى ->> تويه919 \\
\hline$+1+\cdot$ & $\Delta T / \Delta \cdot T$ & $\cdot 1 \cdot 1 \mathrm{~V}$ & .191. & |دراك ريسك ->> تويه •r \\
\hline$+1 \cdots$ & $1 \Lambda F / T \cdot G$ & $\cdot 1 \cdot \cdot \Delta$ &.$/ 99$. & |دراك ريسك -> تويه |r \\
\hline$\bullet /+\bullet$ & $F \Delta / 9 \Delta \wedge$ & $\cdot 1 \cdot 19$ & $\cdot \mid \Lambda \vee G$ & |دراك ريسك -> تويه \\
\hline \multirow[t]{3}{*}{$\bullet 1+}$. & $q T / F \Delta G$ & $\cdot 1 \cdot 1$ & .1949 & |دراك ريسك -> تويه \\
\hline & & $\cdot$ & 1 & EDU >- تحصيلات \\
\hline & & $\cdot$ & 1 & EXP >- تجربه \\
\hline
\end{tabular}

آزمون الكَوى نظرى يزوهش

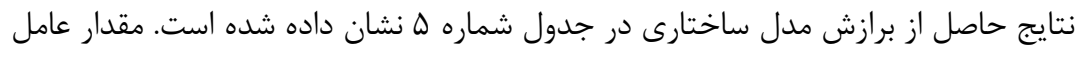

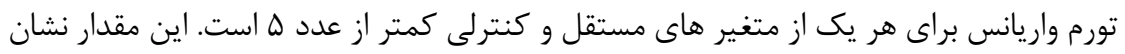


مى دهد كه بين متغير هاى مستقل و كنترلى همخطى معنادارى وجود ندارد. مقادير مثبت

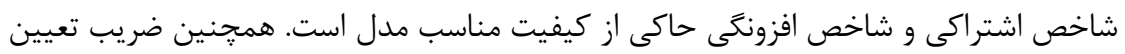

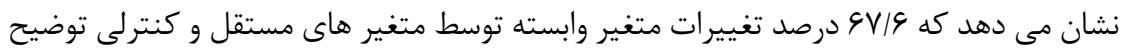
داده مى شود.

جدول شماره ه- نتايج حاصل از برازش مدل ساختارى

\begin{tabular}{|c|c|c|c|}
\hline شاخص افزونكى & شاخص اشتراك & عامل تورم واريانس & متغير ها \\
\hline \multirow[t]{8}{*}{$.194 \lambda$} & $\cdot / V Y V$ & & تمايل به حسابدارى و زَارشخرى پايدارى \\
\hline & $.19 \mathrm{TV}$ & $r / \Delta V \cdot$ & 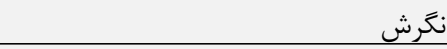 \\
\hline & $\cdot|9| \cdot$ & $r / \Delta 9 \mu$ & هنجارذهنى \\
\hline &.$/ 1 \wedge \mathrm{V}$ & l/qVe & كنترل رفتارى ادراى شده \\
\hline &.$/ 4 F V$ & 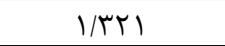 & تعهد اخلاقي \\
\hline & $.19 \wedge \mathrm{F}$ & $r / \Delta \Delta \Lambda$ & ادراى ريسك \\
\hline & 1 & $1 / \% \wedge 9$ & تحصيلات \\
\hline & 1 & $1 / 970$ & تجربه \\
\hline .1990 & ضعديب تعيين شده & $.19 \vee 9$ & ضريب تعيين \\
\hline
\end{tabular}

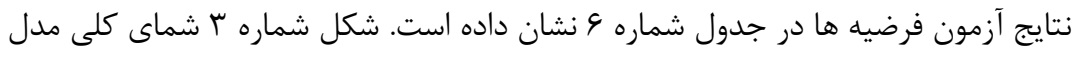

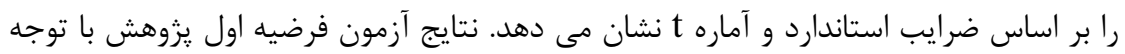

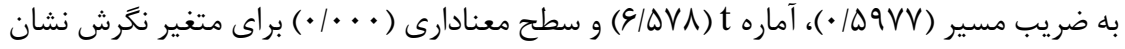

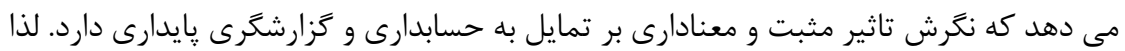

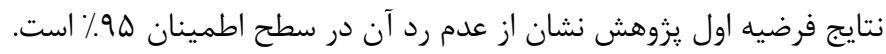

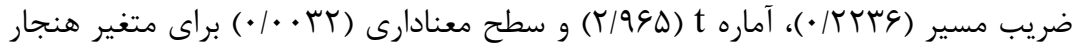

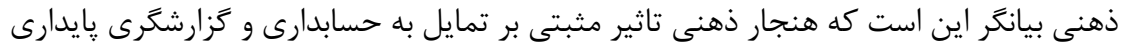

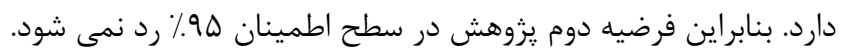

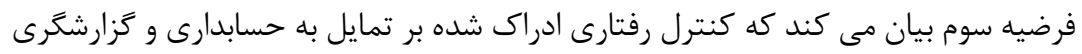

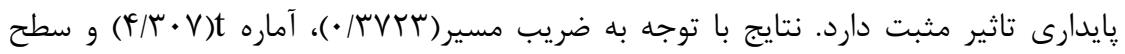

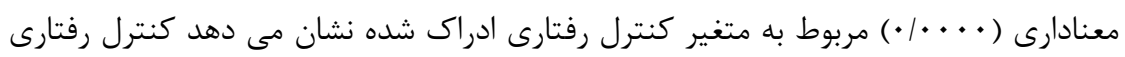

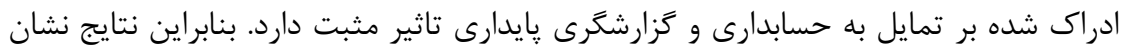

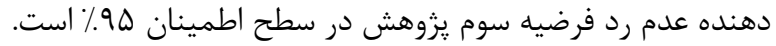

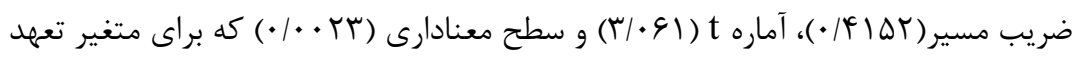

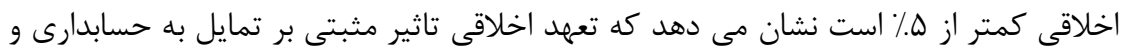

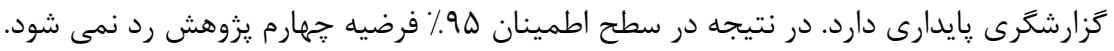




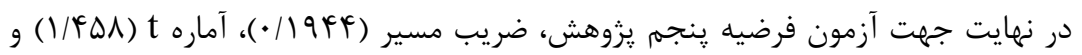

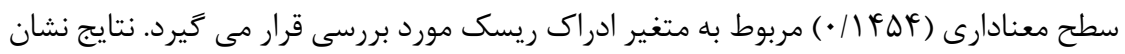

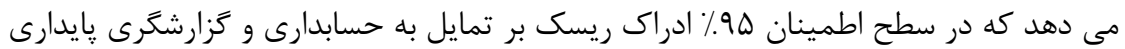

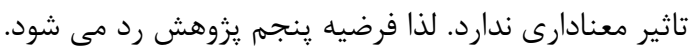

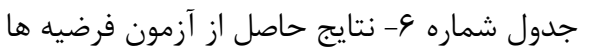

\begin{tabular}{|c|c|c|c|c|}
\hline سطح معنادارى & آماره t & انحراف از استاندارد | & ضريب مسير & مسير \\
\hline$\cdot 1 \cdots$ & s/DVA & $\cdot 1 \cdot 9 \cdot 9$ & . $109 \mathrm{VV}$ & نكرش \\
\hline.$/ . M T$ & r/99D & $.1 \cdot V \Delta F$ & . ItrTE & هنجار ذهنى ـ تمايل \\
\hline$\cdot 1 \cdot \cdots$ & $F / r \cdot V$ & $.1 \cdot \wedge \& 4$ & . TVKT & كنترل رفتارى \\
\hline 情 & $r / .91$ & $\cdot / 1 r \Delta V$ & - IFIOT & تعهد اخلاقى ـ تمايل \\
\hline.$/ 1 F \Delta F$ & $1 / 4 \Delta \Lambda$ & משrו1. &.$/ 19 f F$ & ادراك ريسك ؟ تمايل \\
\hline$\cdot / \cdot \Delta q$ & T/VAT &.$/ . \Delta 9 \mu$ &.$- / 19 \Delta T$ & تجربه זتمايل \\
\hline.$/ 1190$ & I/QVK & $.1 .9 \Delta \mathrm{V}$ & תr (1/ & تحصيلات \\
\hline
\end{tabular}

شكل شماره ب - مدل براساس ضرايب استاندارد (آماره t)
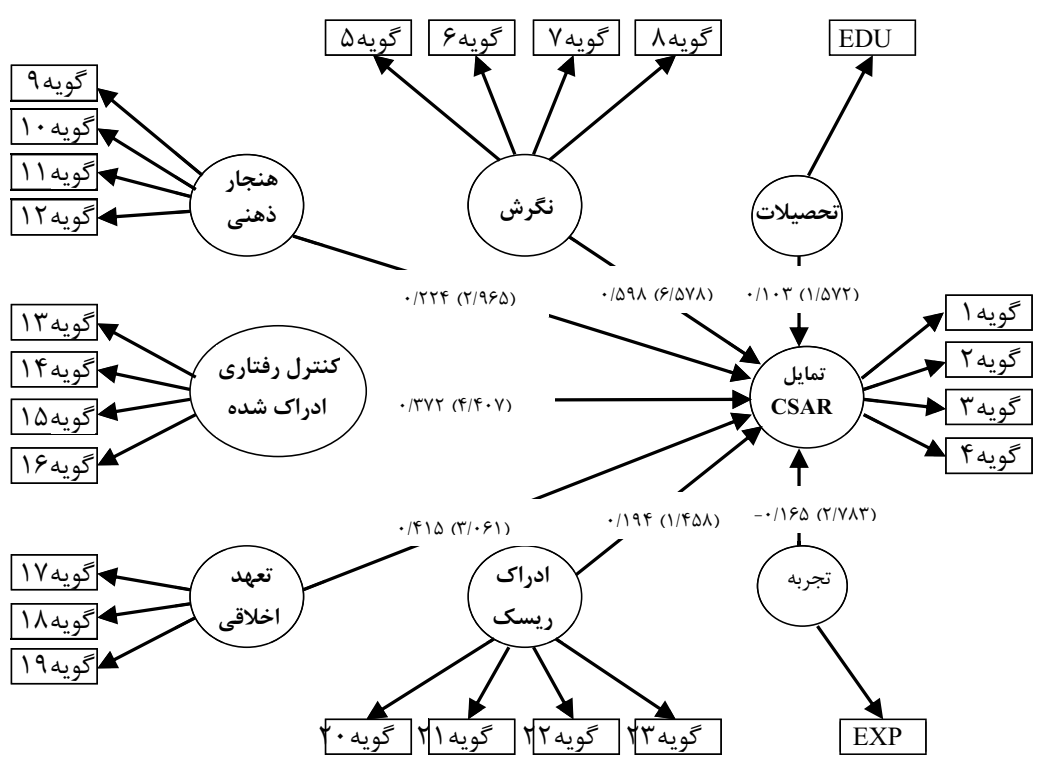

9-بحث و نتيجه تيرى 
هدف از اين يزوهش، بررسى نقش نخرش، هنجارذهنى، كنترل رفتارى ادراك شده، تعهد

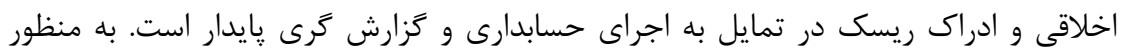

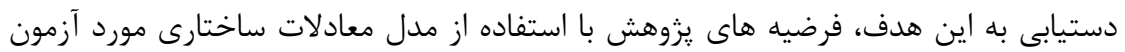

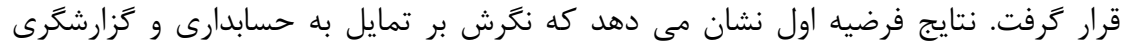

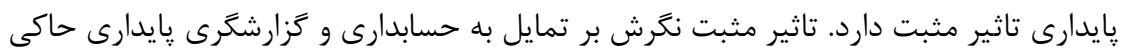

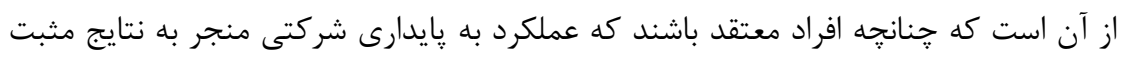

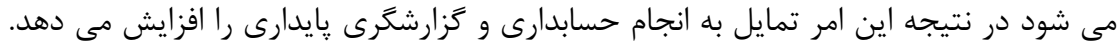

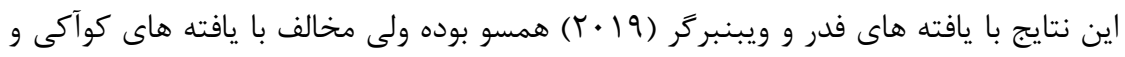

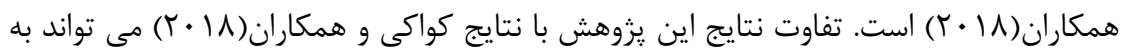

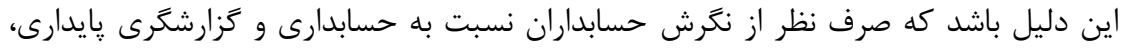

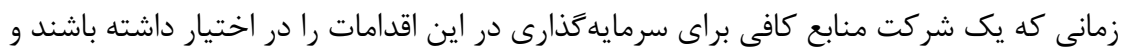

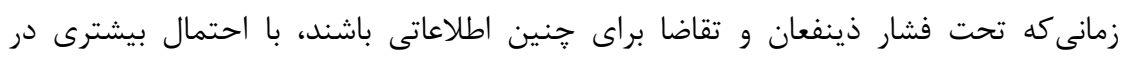

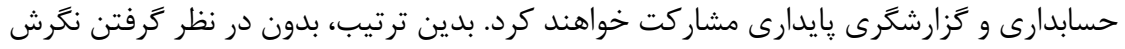

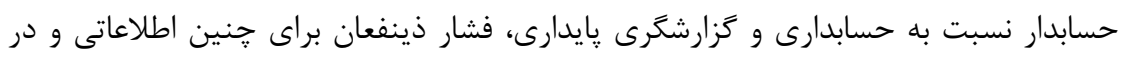

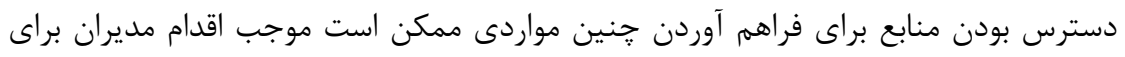

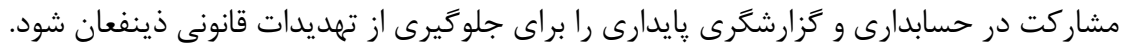

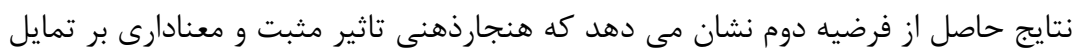

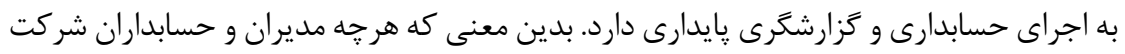

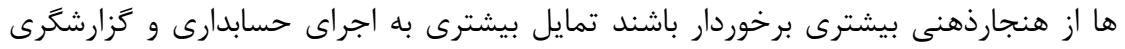

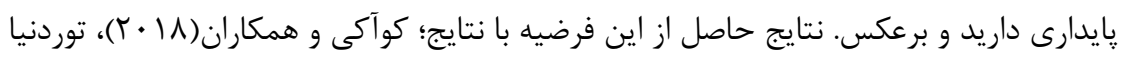

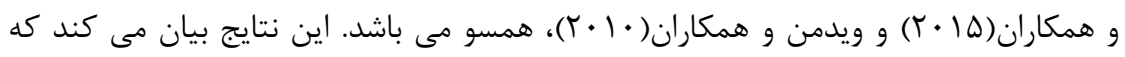

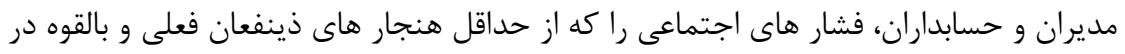

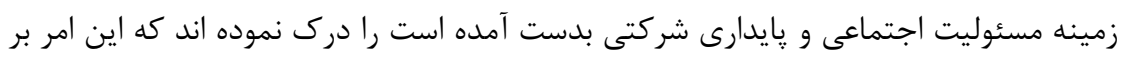

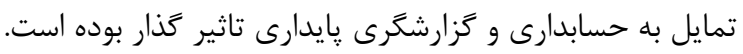

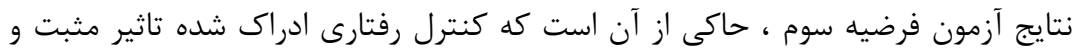

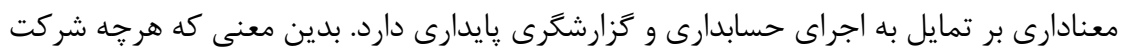

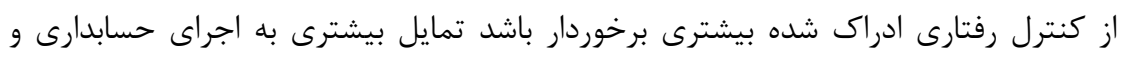

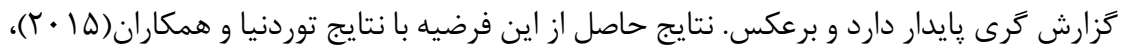

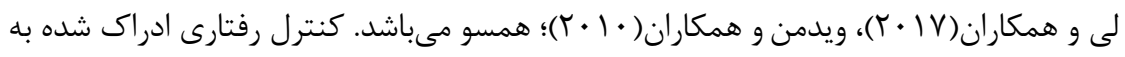

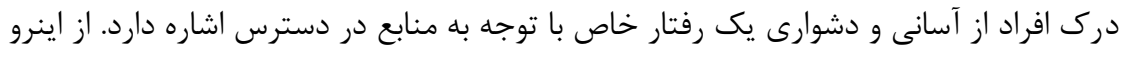


קنانجه منابع مورد نياز براى حسابدارى و گزارشكَى پايدارى براى مديران و حسابداران در

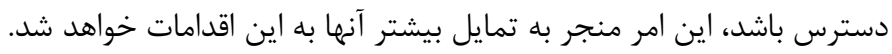

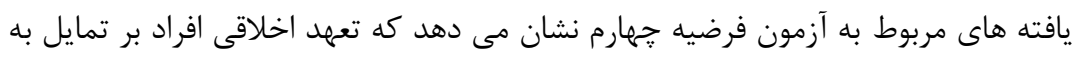

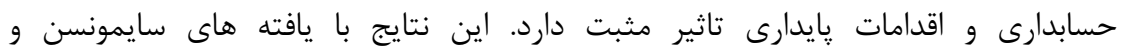

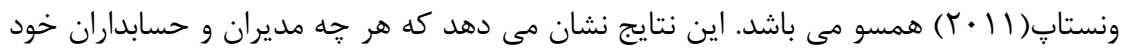

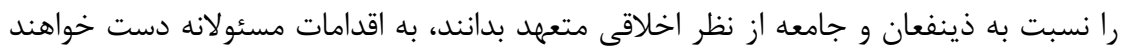

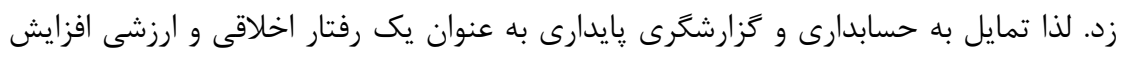

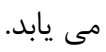

بررسى نتايج حاصل از آزمون فرضيه ينجمم نشان داد كه ادراك ريسك اثر ماند معنادارى بر تمايل

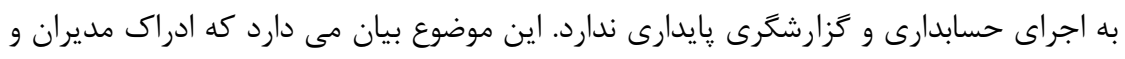

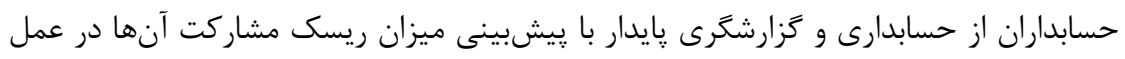

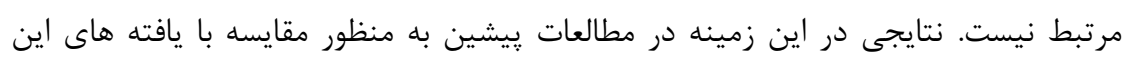

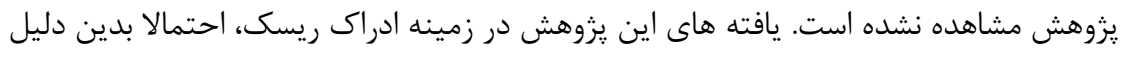

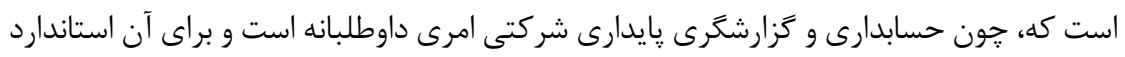

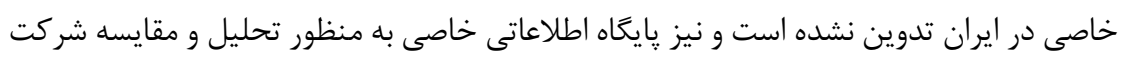

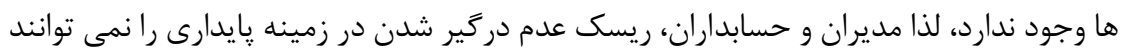
بدرستى برآورد نمايند.

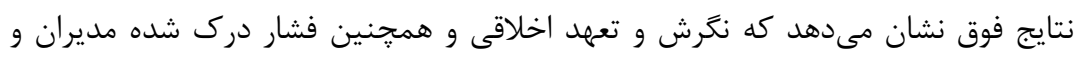

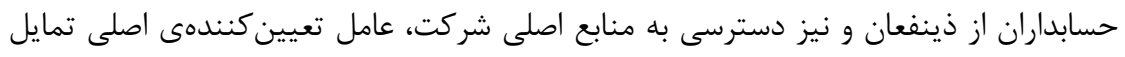

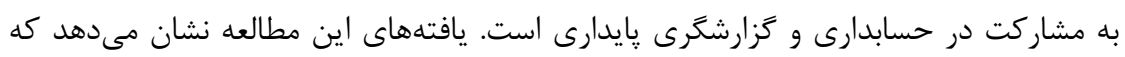

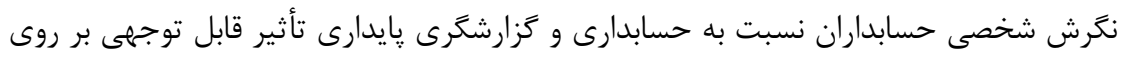

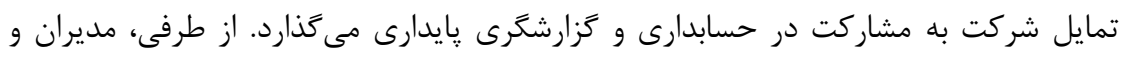

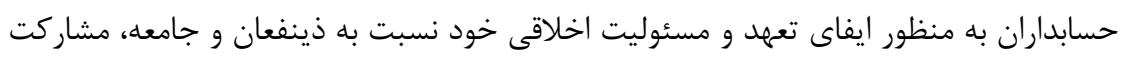

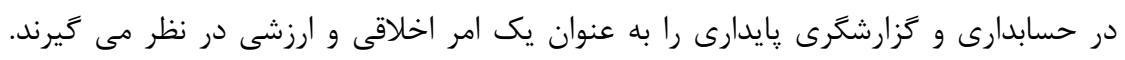

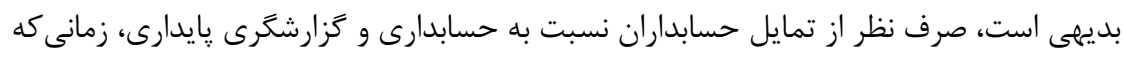

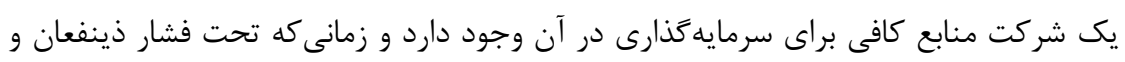

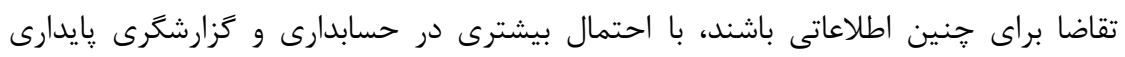

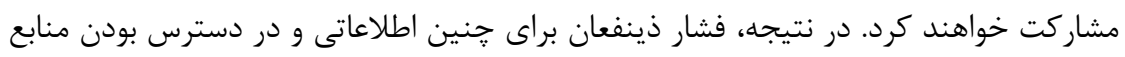

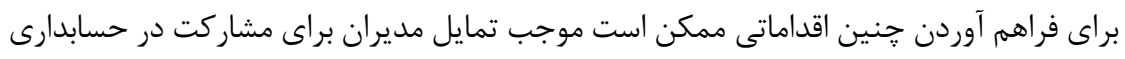

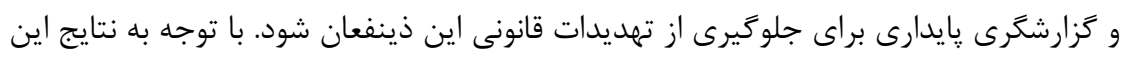


يزوهش به شركت ها يِيشنهاد مى شود تا با توسعه برنامه هاى آموزشى، ايجاد ساختار مناسب،

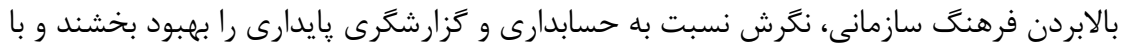

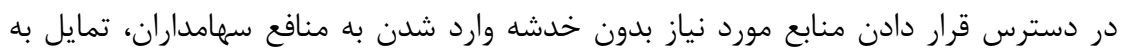

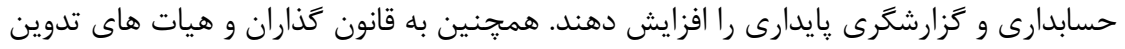

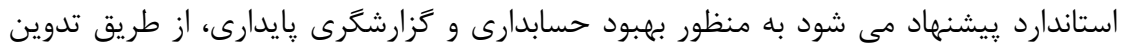

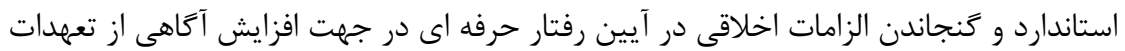

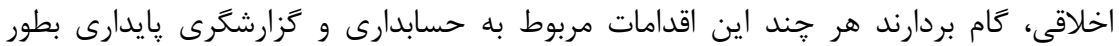

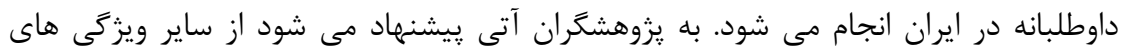

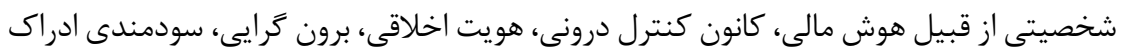

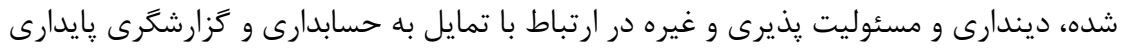

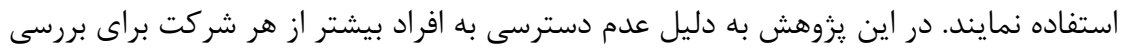

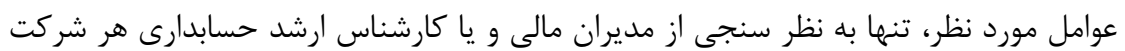
بسنده شده است كه موجب تضعيف تعميم آن به كل شركت مى شود و از محدوديت هاى اين ئزوهش محسوب مى كردد.

V- تقدير، تشكر و ملاحظه هاى اخلاقى

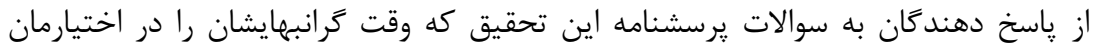

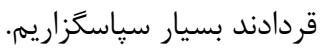
1 - يیيوست ها:

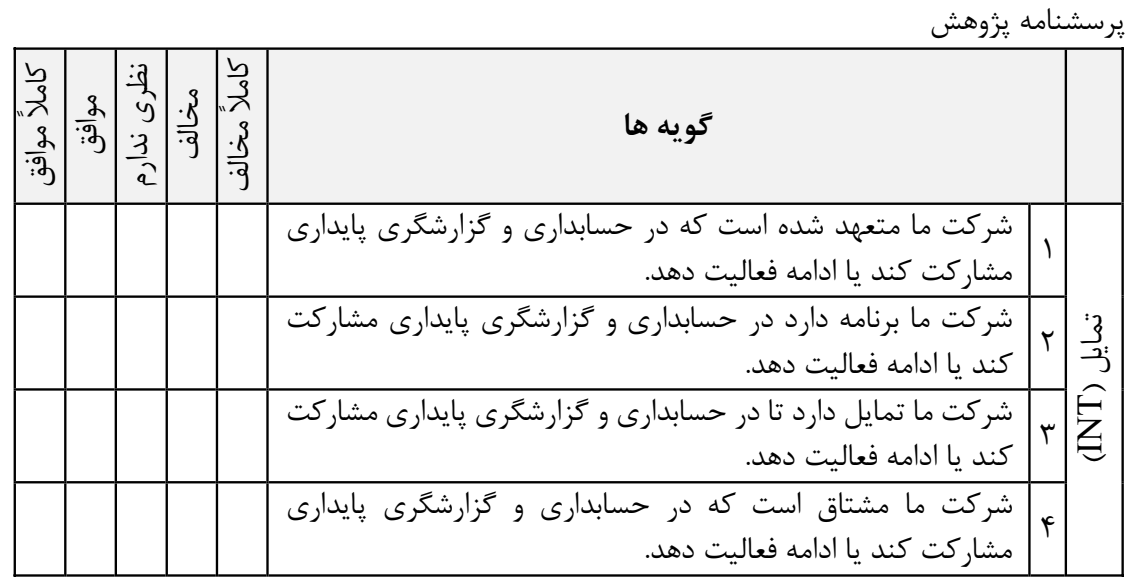


دو فصلنامه حسابدارى ارزشى و رفتارى، سال ينجم، شماره نهم، بهار و تابستان 99"1

\begin{tabular}{|c|c|c|c|c|c|}
\hline & & & دركير شدن در حسابدارى و گزارشگَى يايدارى براى شركت ما خوب & $\Delta$ & \multirow{4}{*}{$: \frac{1 i_{2}}{3}$} \\
\hline & & & ارزشمير شدن است. در حسابدارى و كزارشگرى گايدارى براى شركت ما & 4 & \\
\hline & & & درَير شدن در حسابدارى و گزارشكَى پايدارى براى شركت ما مفيد & $v$ & \\
\hline & & & دار استير شدن در حسابدارى و گَزارشكَرى پايدارى براى شركت ما معنى & $\wedge$ & \\
\hline & & & 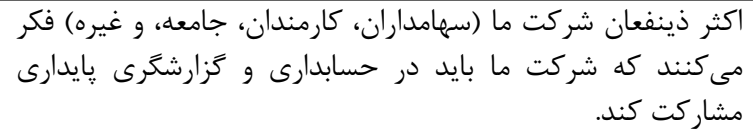 & 9 & ? \\
\hline & & & 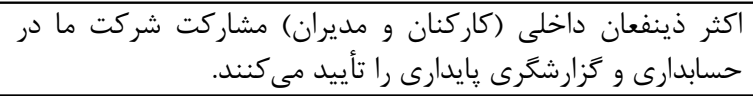 & $1 \cdot$ & $\hat{2}$ \\
\hline & & & 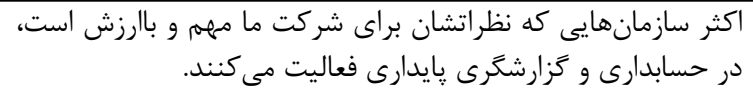 & 11 & $\widehat{\widehat{z}}$ \\
\hline & & & بايدارى فعاليت از شركتهاى مشارند. & $I T$ & \\
\hline & & & مشاركت در حسابدارى و كزارشخرى پِايدارى براى شركت ما آسان & سו & $y$ \\
\hline & & & مشير است. مرت حسابدارى و گزارشكرى پايدارى براى شركت ما امكان & 14 & 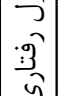 \\
\hline & & & شايدارى را دارد ما اختيار تصميم به مشاركت در حسابدارى و گزارشكَىى & 10 & $\frac{5}{5}$ \\
\hline & & & شركت ما تصميم به مشاركت در حسابدارى و كزارشكرى یايدارى را & 19 & :3 \\
\hline & & & كند. شت ما با عدم حسابدارى و گززارشخرى پايدارى احساس گَناه مى & $\mathrm{IV}$ & 9 \\
\hline & & & يايدارى اشتباه است ما، از نظر اخلاقى، عدم اجراى حسابدارى و گزارشخرى & $1 \wedge$ & $\frac{3}{. \bar{y}}$ \\
\hline & & & ما است. حسابدارى و كزارشخرى پايدارى بر خلاف اصول و موازين شركت & 19 & \\
\hline & & & شركت را در بلند مدت مان كاهش كه عدم حسابدارى و گزارشخرى پايدارى، ارزش & $\tau$. & $3^{?}$ \\
\hline & & & 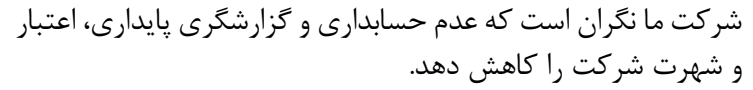 & TI & $\frac{5}{5}$ \\
\hline & & & 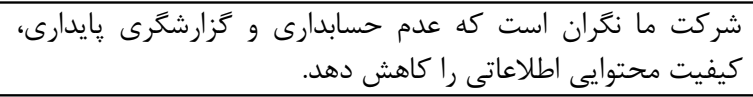 & $\pi$ & *3 \\
\hline
\end{tabular}


بينشيان، زهرا و دهدار، فرهاد.(Y Y I )، ارائه مدل رابطه هوش مالى با گرايشهاى رفتارى و اثر

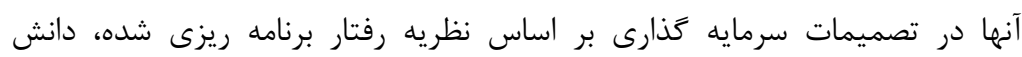

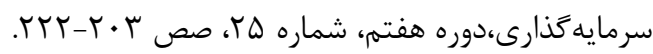

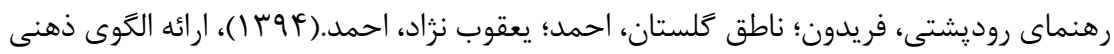
ادراى ريسك سرمايه حذاران بورس اوراق بهادار تهران، فصلنامه دانش سرمايهَّارى،

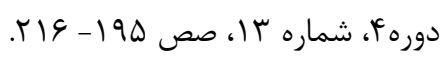

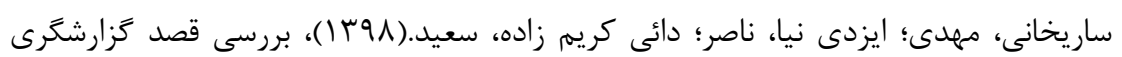

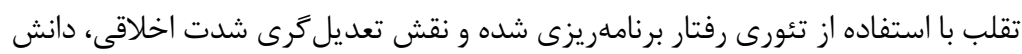

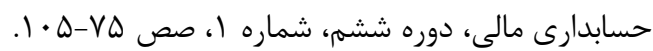

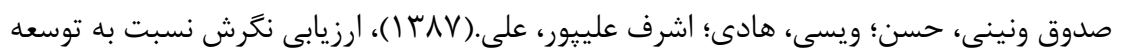

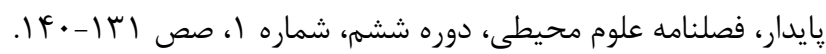

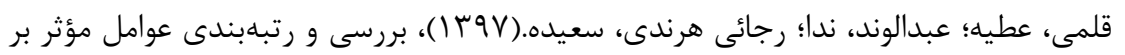

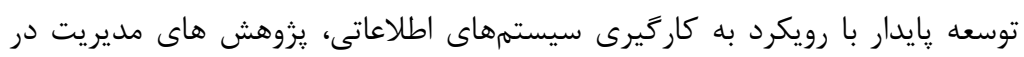

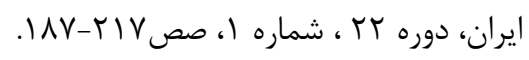

فراتى، حسن؛ خلج، اميد؛ نور موسوى، مهدى.(91 (1)، عوامل مؤثر بر مصرف سبز بر اساس نظريه

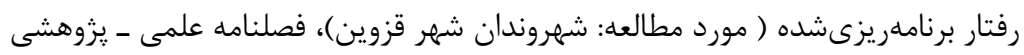

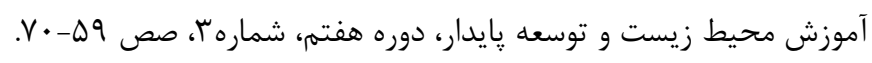

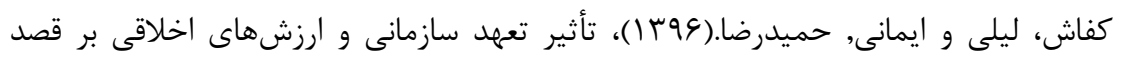
زَزارش تخلفهاى كشفشده در بين حسابداران بخش عمومى، حسابدارى سلامت، دوره

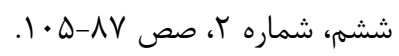

معصومى، سيد رسول؛ صالحنزاد، سيد حسن؛ ذبيحى زرين كلايى، على.(I IVY)، بررسى تأثير

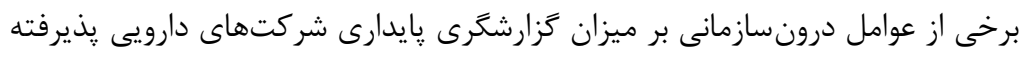

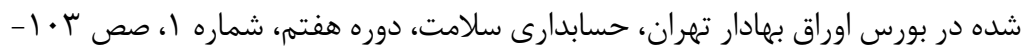

$.1 T 9$

ناطق كلستان، احمد.(צوس ()، بررسى وجود اثرات ادراك ريسك در بورس اوراق بهادار تهران و

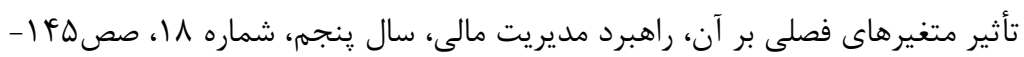


Adams, C. A. 2002. Internal organizational factors influencing corporate social and ethical reporting: Beyond current theorising. Accounting, Auditing \& Accountability Journal 15(2): 223-250.

Adams, C. A., and P. McNicholas. 2007. Making a difference: Sustainability reporting, accountability and organisational change. Accounting, Auditing \& Accountability Journal 20(3): 382-402.

Adams, C. A., and G. Whelan. 2009. Conceptualizing future change in corporate sustainability reporting. Accounting, Auditing \& Accountability Journal 22(1): 118-143.

Ajzen, I. 2011. Editorial: The theory of planned behavior: Reactions and reflections. Psychology and Health 26 (9): 1113-1127.

Ajzen, I. 1991. The theory of planned behavior. Organizational Behavior and Human Decision Processes 50(2): 179-211.

Ajzen, I., and M. Fishbein. 1980. Understanding attitudes and predicting social behaviour. Englewood Cliffs: Prentice-Hall.

Alam, S. M., and S. Akter. 2019. Understanding the Interplay among the Factors of Behavioral Intention Regarding Environmental Reporting. International Journal of Scientific \& Technology Research 8(11): 2657-2663.

Aras, G., and D. Crowther. 2008. Governance and sustainability: an investigation into relationship between corporate governance and corporate sustainability. Management Decision 46(3): 443448.

Aras, G., and D. Crowther. 2009a. Corporate sustainability reporting: A study in disingenuity? . Journal of Business Ethics 87(1): 279-288.

Aras, G., and D. Crowther. 2009b. Making sustainable development sustainable. Management Decision 47(6): 975-988.

Armitage, C. J., and M. Conner. 2001. Efficacy of the Theory of Planned Behavior: A meta-analytic review. British Journal of Social Psychology 40(4): 471-499.

Bebbington, J., R. Gray, I. Thomson, and D. Walter. 1994. Accountants' attitudes and environmentally-sensitive accounting. Accounting and Business Research 24(94): 109-120.

Beck, L., and I. Ajzen. 1991. Predicting dishonest actions using the theory of planned behavior. Journal of Research in Personality 25(3): 285-301.

Bineshian, Z., and F. Dehdar. 2018. Present the Model of the relationship between financial intelligence behavioral trends and their impact on investors decisions based on the theory of planned behavior. Journal of Investment Knowledge 7(25): 203-222.(In Persian)

Burritt, R. L., and S. Schaltegger. 2010. Sustainability accounting and reporting: Fad or trend? Accounting, Auditing \& Accountability Journal 23(7): 829-846.

Cordano, M., and I. H. Frieze. 2000. Pollution reduction preferences of US environmental managers: Applying Ajzen's theory of planned behavior. The Academy of Management Journal 43(4): 627-641.

Cunningham, S. M. 1967. The major dimensions of perceived risk. In: Cox DF, editor. Risk taking and information handling in consumer behavior. Boston: Harvard University Press. 


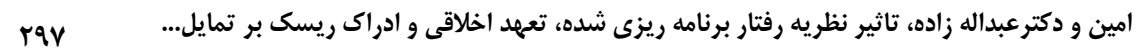

Deegan, C., and B. Gordon. 1996. A study of the environmental disclosure practices of Australian corporations, Accounting and Business Research 26(3): 187199.

Dubbink, W. 2014. A moral grounding of the duty to further justice in commercial life. Ethical Theory and Moral Practice 1: 27-45.

Featherman M. S., and P. A. Pavlou. 2003. Predicting e-services adoption: a perceived risk facets perspective. Int J Hum Comput Stud 59(4):451-74.

Feder, M., and B. E. Weißenberger. 2019. Understanding the behavioral gap: Why would managers (not) engage in CSR-related activities? J Manag Control 30(1): 95-126. DOI:10.1007/s00187-019-00275-y.

Fishbein, M., and I. Ajzen. 1975. Belief, attitude, intention and behavior: An introduction to theory and research. Reading, Mass, Addison Wesley Publishing Company.

Freedman, M., and B. Jaggi. 2010. Global warming and corporate disclosures: A comparative analysis of companies from the European Union, Japan and Canada. Advances in Environmental Accounting and Management: Sustainability, Environmental Performance and Disclosures 4:129-160.

Gadenne, D. L., J. Kennedy, and C. McKeiver. 2009. An empirical study of environmental awareness and practices in SMEs. Journal of Business Ethics 84(1): 45-63.

Goyal, P., and D. Kumar. 2017. Modeling the CSR barriers in manufacturing industries. Benchmarking: An International Journal 24(7): 1871-1890.

Global Reporting Initiative (GRI) standard, Foundation. 2016. (Containing Standard Interpretation 1). GRI 101. Effective From: 01 Jul 2018.

Guenther, E., J. Endrikat, and T. W. Guenther. 2016. Environmental management control systems: A conceptualization and a review of the empirical evidence. Journal of Cleaner Production 136(Part A): 147-171.

Ha-Brookshire, J. 2017. Toward Moral Responsibility Theories of Corporate Sustainability and Sustainable Supply Chain. J Bus Ethics 145(2): 227-237. https://doi.org/10.1007/s10551-015-2847-2.

Hair Jr, J. F., G. T. M. Hult, C. Ringle, and M. Sarstedt. 2016. A primer on partial least squares structural equation modeling (PLS-SEM). Sage Publications.

Henriques, I., and P. Sadorsky. 1999. The relationship between environmental commitment and managerial perceptions of stakeholder importance. Academy of Management Journal 42(1): 87-99.

Herzig, C., and S. Schaltegger. 2011. Corporate sustainability reporting: an overview, in Bennett, $M$ and Buritt, R.L. (Eds). Sustainability Accounting and Reporting. Kluwer Academic Publishers. Boston Dordrecht/London: 301324.

Hines, J. M., H. R. Hungerford, and A. N. Tomera. 1987. Analysis and synthesis of research on responsible environmental behaviour: A meta-analysis. Journal of Environmental Education 18: 1-8.

KPMG. 2011. International survey of corporate responsibility reporting . New York: KPMG International. 
Kuzey, C., and A. Uyar. 2017. Determinants of sustainability reporting and its impact on firm value: evidence from the emerging market of Turkey. Journal of Cleaner Production 143: 27-39.

Kwakye, T.O., E. E. Welbeck, G. M. Y. Owusu, and F. K. Anokye. 2018. Determinants of intention to engage in Sustainability Accounting \& Reporting (SAR): the perspective of professional accountants. Int $\mathrm{J}$ Corporate Soc Responsibility 3(1): 1-13. DOI:10.1186/s40991-018-0035-2.

Lamberton, G. 2005. Sustainability accounting - A brief history and conceptual framework. Paper read at Accounting Forum.

Lee, W. E., R. N. Birkey, and D. M. Patten. 2017. Exposing students to environmental sustainability in accounting: An analysis of its impacts in a US setting. Social and Environmental Accountability Journal, 37(2), 81-96.

Lewis, L. 2000. Environmental audits in local government: A useful means to progress in sustainable development. Paper read at Accounting Forum.

Lin W. B. 2008. Investigation on the model of consumers' perceived risk - integrated viewpoint. Expert Syst Appl 34(1): 977-88.

Lusher, A. L. 2012. What is the accounting Profession's role in accountability of economic, social, and environmental issues?. International Journal of Business and Social Science 3(15): 13-19.

Martin, A., and D. Hadley. 2008. Corporate environmental non-reporting-a UK FTSE 350 perspective. Business Strategy and the Environment 17(4): 245259.

Mellema, G. 2006. Collective responsibility and qualifying actions. Midwest Studies in Philosophy 30: 176-193.

Mustikasari, E. 2009. Empirical Study on Taxpayer Compliance Agency in Manufacturing Industry Company in Surabaya National Seminar on Accounting X. Makasar: 1-17.

O’Dwyer, B. 2002. Managerial perceptions of corporate social disclosure: An Irish story. Accounting, Auditing \& Accountability Journal 15(3): 406-436.

Oktavianti, T. Ratnawati, S. Riyadi, and H. Panjaitan. 2017. Subjective Norm, Moral Obligation, and Perceived Behavioral Control, As Antecedents Variable Is Service Quality, Attitude and Intention To Compliance With Taxpayers: (Study on Motor Vehicle Tax in Riau Islands Province). Journal of Research in Business and Management 5(4): 32-40.

Özsözgün Çalişkan, A. 2014. How accounting and accountants may contribute in sustainability? Social Responsibility Journal 10(2): 246-267.

Peter J. P., and M. J. Ryan. 1976. An investigation of perceived risk at the brand level. J Market Res 13:184-8.

Pondeville, S., V. Swaen, and Y. De Rongé. 2013. Environmental management control systems: The role of contextual and strategic factors. Management Accounting Research 24(4): 317-332.

Rahnamay Roodposhti, F., A. Nategh Golestan, and A. Yaghoobnezhad. 2014. Investigation of risk perception mental model of investors of Tehran Stock Exchange. Journal of Investment Knowledge 4(1): 195-216.(In Persian)

Ricciardi, V. 2008. Handbook of Finance: Investment Management and Financial Management. ch10. Published by John Wiley \& Sons. 
Rubenstein, D.B. 1992. Bridging the gap between green accounting and black ink. Accounting Organizations \& Society 17(5): 501-508.

Schaltegger, S., D. Gibassier, and D. Zvezdov. 2013. Is environmental management accounting a discipline? A bibliometric literature review. Meditari Accountancy Research 21(1): 4-31.

Schwartz, H. 1998. Rationality Gone Awry? Decision Making Inconsistent with Economic and Financial Theory. Westport. CT: Greenwood Publishing Group. Inc.

Simonsen, C.D., and S. Wenstøp. 2011. Companies' Ethical Commitment - An Analysis Of The Rhetoric In CSR Reports. Issues in Social and Environmental Accounting 5(1/2): 65-81.

Sisaye, S. 2011a. Ecological systems approaches to sustainability and organizational development: Emerging trends in environmental and social accounting reporting systems. Leadership and Organization Development Journal 32(4): 379-398.

Sisaye, S. 2011b. The functional-institutional and consequential-conflictual sociological approaches to accounting ethics education: Integrations from sustainability and ecological resources management literature. Managerial Auditing Journal 26(3): 263-294.

Starik, M., and P. Kanashiro. 2013. Toward a theory of sustainability management: Uncovering and integrating the nearly obvious. Organization \& Environment 26(1): 7-30.

Sustainability Accounting Standards Board (SASB). 2016. SASB Exposure Draft. Retrieved June 27.

Thoradeniya, P., J. Lee, R. Tan, and A. Ferreira. 2015. Sustainability reporting and the theory of planned behaviour. Accounting, Auditing \& Accountability Journal 28(7): 1099-1137.

Tuu, H. H., and S. O. Olsen. 2012. Certainty, risk and knowledge in the satisfaction - purchase intention relationship in a new product experiment. Asia Pacific of Marketing and Logistics 24(1): 78-101.

Watson, R. T., M. C. Boudreau, and A. J. Chen. 2010. Information systems and environmentally sustainable development: energy informatics and new directionsfor the IS community. MIS quarterly 3(1): 23-38.

Weidman, S. M., A. P. Curatola, and F. Linnehan. 2010. An experimental investigation of the intentions to accrue and disclose environmental liabilities. In Ethics, Equity, and Regulation 15: 195-243.

Wilmshurst, T. D., and G. R. Frost. 2001. The role of accounting and the accountant in the environmental management system. Business Strategy and the Environment 10(3): 135-147. 